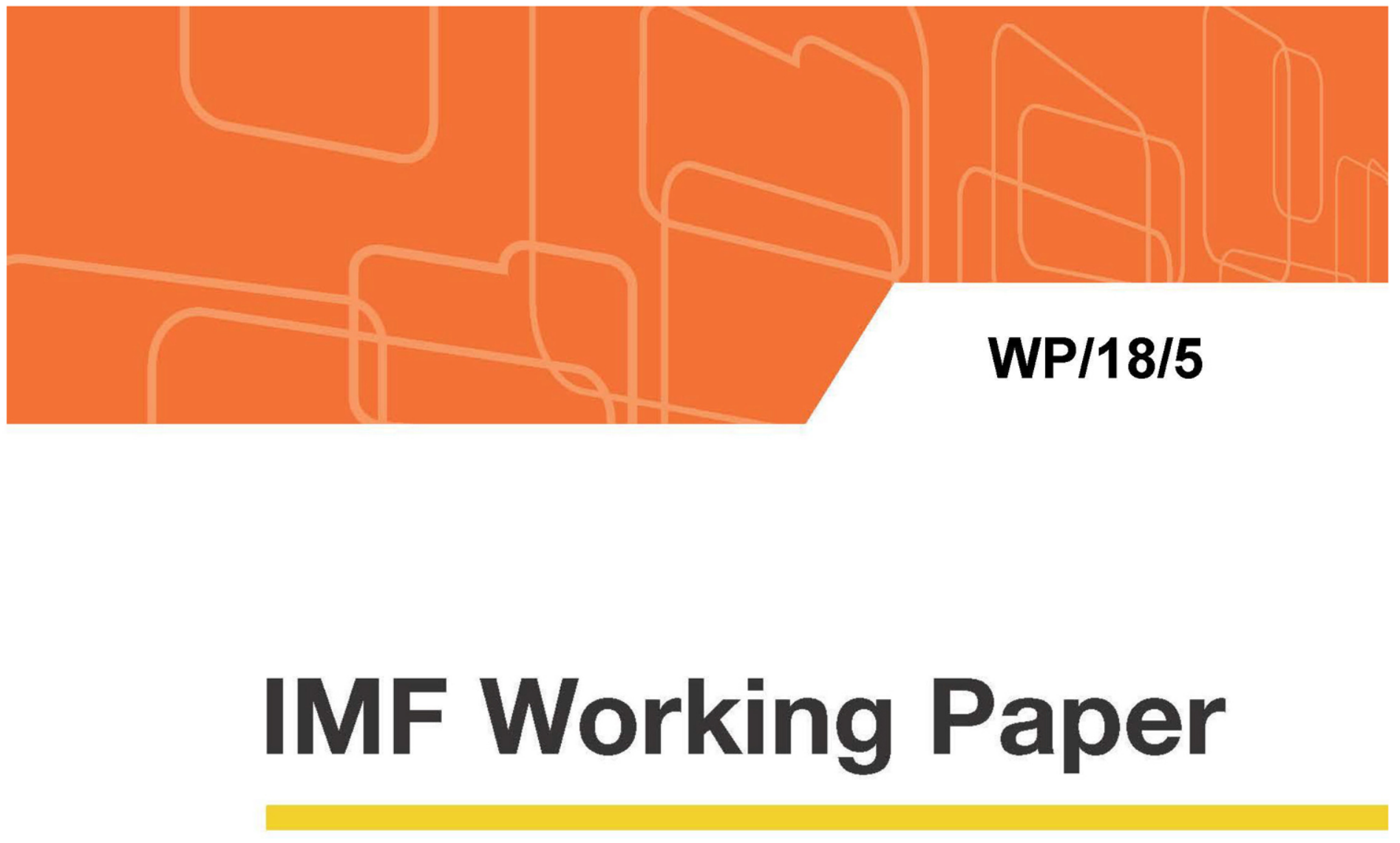

\title{
Growth-Equity Trade-offs in Structural Reforms
}

\author{
Jonathan D. Ostry, Andrew Berg, and Siddharth Kothari
}

IMF Working Papers describe research in progress by the author(s) and are published to elicit comments and to encourage debate. The views expressed in IMF Working Papers are those of the author(s) and do not necessarily represent the views of the IMF, its Executive Board, or IMF management. 


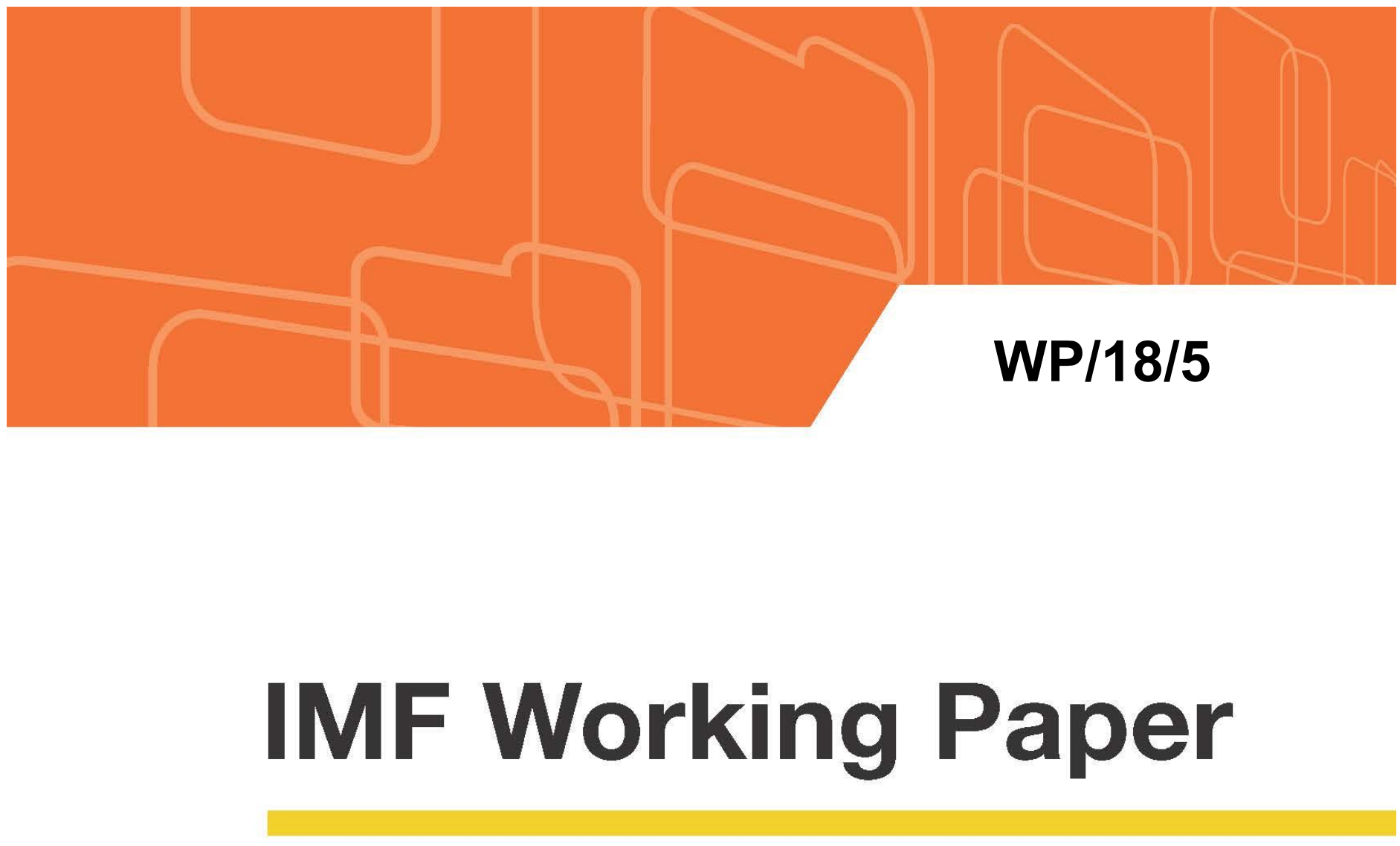

\title{
Growth-Equity Trade-offs in Structural Reforms
}

\author{
Jonathan D. Ostry, Andrew Berg, and Siddharth Kothari
}

IMF Working Papers describe research in progress by the author(s) and are published to elicit comments and to encourage debate. The views expressed in IMF Working Papers are those of the author(s) and do not necessarily represent the views of the IMF, its Executive Board, or IMF management.

I N T E R N A T I O N A L M O N 


\title{
IMF Working Paper
}

\author{
Research Department
}

\section{Growth-Equity Trade-offs in Structural Reforms ${ }^{1}$}

\section{Prepared by Jonathan D. Ostry, Andrew Berg, and Siddharth Kothari}

Authorized for distribution by Jonathan D. Ostry

January 2018

\begin{abstract}
IMF Working Papers describe research in progress by the author(s) and are published to elicit comments and to encourage debate. The views expressed in IMF Working Papers are those of the author(s) and do not necessarily represent the views of the IMF, its Executive Board, or IMF management.
\end{abstract}

\begin{abstract}
Do structural reforms that aim to boost potential output also change the distribution of income? We shed light on this question by looking at the broad patterns in the cross-country data covering advanced, emerging-market, and low-income countries. Our main finding is that there is indeed evidence of a growth-equity tradeoff for some important reforms. Financial and capital account liberalization seem to increase both growth and inequality, as do some measures of liberalization of current account transactions. Reforms aimed at strengthening the impartiality of and adherence to the legal system seem to entail no growth-equity tradeoff-such reforms are good for growth and do not worsen inequality. The results for our index of network reforms as well as our measure of the decentralization of collective labor bargaining are the weakest and least robust, potentially due to data limitations. We also ask: If some structural reforms worsen inequality, to what degree does this offset the growth gains from the reforms themselves? While higher inequality does dampen the growth benefits, the net effect on growth remains positive for most reform indicators.
\end{abstract}

JEL Classification Numbers: O11, O15, O47, P11

Keywords: Structural Reforms, Growth, Inequality

Author’s E-Mail Address: JOstry@imf.org; ABerg@imf.org; SKothari@imf.org

\footnotetext{
${ }^{1}$ The authors are grateful to Romain Duval and Davide Furceri for helpful comments, to Prakash Loungani and Ke Wang for their review of country cases in the paper, to Yorbol Yakhshilikov for superb research support, and to Anne Lalramnghakhleli Moses for excellent assistance.
} 
I. INTRODUCTION

II. A REVIEW OF THE LITERATURE __

III. REFORMS DATA _ 7

IV. GROWTH-EQUITY TRADE-OFFS: AN ASSESSMENT FRAMEWORK _ 10

V. GROWTH-EQUITY TRADE-OFFS IN REFORMS: RESULTS __

A. Domestic Finance Reforms

B. Capital Account Liberalization __ $\frac{17}{17}$

C. Rule of Law _ 17

D. Current Account Liberalization __

E. Networks Reform

F. Collective Bargaining Reforms

G. Reforms, Growth, and Inequality: A Look at Country Cases __ 26

VI. STRUCTURAL REFORMS, INEQUALITY, AND GROWTH: A SIMPLE

CALCULATION

VII. CONCLUSION

\section{FIGURES}

Figure 1. Box Plots of Reform Indices

Figure 2. Reform Indices Over Time by Income Level

Figure 3. Domestic Finance Reforms: Growth and Inequality Around Breaks

Figure 4. Capital Account Liberalization: Growth and Inequality Around Breaks

Figure 5. Tariff Liberalization: Growth and Inequality Around Breaks

Figure 6. Current Account Liberalization: Growth and Inequality Around Breaks __ 22

Figure 7. Network Reforms: Growth and Inequality Around Breaks _ 24

Figure 8. Collective Bargaining: Growth and Inequality Around Up-breaks

Figure 9. Collective Bargaining: Growth and Inequality Around Down-breaks __ 26

Figure 10: Growth and Inequality Effects of Structural Reforms __ 27

Figure 11: Short-term Effect of Reforms on Growth__ 28

Figure 12. Country Cases: Growth, Inequality \& Structural Reform Episodes

Figure 13: Direct and Indirect Effect of Reforms on Steady State Level of Per-capita GDP __

TABLES

Table 1. Domestic Finance Reforms: Growth-Equity Trade-off

Table 2. Subcomponents of Domestic Finance Reforms Index: Growth-Equity Trade-off __

Table 3. Capital Account Liberalization: Growth-Equity Trade-off __ 18

Table 4. Rule of Law: Growth-Equity Trade-offs

Table 5. Tariff Liberalization: Growth-Equity Trade-off

Table 6. Current Account Liberalization: Growth-Equity Trade-off___ 21

Table 7. Networks Reforms: Growth-Equity Trade-off

Table 8. Collective Bargaining Reforms: Growth-Equity Trade-offs __ 25

APPENDICES

Appendix I: Reforms Data ___ $\underline{40}$

Appendix II: Algorithm for finding Reform Episodes

Appendix III: Country Classification by Income Group ___ $\underline{43}$

References 


\section{INTRODUCTION}

The global recovery since the financial crisis has been weak and uneven, with fear of secular stagnation in advanced economies and a slowdown in potential output growth in many emerging and developing economies. In addition, the lower bound on the nominal policy interest rate and the buildup of public debt after the crisis has left little space for traditional monetary and fiscal policy to boost output and employment. In this environment, there is growing interest in structural reforms (broadly defined to include all reforms that lead to a more efficient allocation of resources) to provide a durable fillip to economic growth.

A second worrisome trend is the widespread increase in inequality seen within many countries over the last few decades. Some inequality is an integral part of the incentive structure in a market-based economy. However, rising inequality has a range of pernicious social and political effects, including supporting the recent rise in populism, isolationism, and protectionism. Rising inequality might have been tolerated during the period of great moderation but, in a period of slow growth, support for globalization and pro-growth reforms has been waning, with rising inequality a contributing factor. It is tempting to think that if policy makers could simply get growth going, inequality would take care of itself. Unfortunately, recent work suggests this is a dangerous gamble-slow or fragile growth and high inequality seem to be two sides of the same coin, and durable growth at a healthy pace will only be possible if growth itself becomes more inclusive, likely requiring policy intervention (Berg and Ostry, 2011, 2012; Ostry et al., 2014; Ostry, 2014).

While there is a consensus that structural reforms can increase growth, and are therefore an important element of the policy toolkit in the current environment, there is also a fear that certain reforms could further exacerbate inequality. It is clear that reforms produce both "winners" and "losers", and it is perhaps the opposition of the losers that make reforms so difficult to implement politically. As a senior European policy maker recently lamented: "We all know what to do; we just don't know how to get re-elected after we've done it." Moreover, if the losers from reforms are concentrated among those who are already less advantaged, then reforms can indeed increase inequality, which in turn can reduce the level and sustainability of growth. More generally, structural reforms generally aim to allow market forces to play a larger role. As suggested by many strands of the literature, they may therefore induce greater inequality insofar as those members of society best able to take advantage of the greater role of market incentives tend to be those with better initial conditions.

To get a full picture of the economic impact of reforms requires a nested approach, one which can assess the impact of reforms on both growth and inequality. Such an approach is also essential to allow for the possible feedback from reform-induced changes in inequality to growth. The total effect on growth consists of the direct effect that reforms engender plus the indirect effect operating through the change in inequality. In this paper we therefore ask the following questions: Do reforms entail an equity-efficiency trade-off? In particular, do reforms which increase growth also increase inequality and, through the increase in inequality, potentially dampen the growth increase from the reform?

We adopt a macroeconomic frame to answer these questions. We use a cross-country approach covering data from advanced, emerging-market, and low-income countries - the encompassing nature of our dataset speaks to the global relevance of our results. We use two complementary 
methods - panel (growth and inequality) regressions and an event-study approach - to assess the aggregate relation among growth, inequality, and reforms. We also undertake an overview of select country cases to illustrate a number of findings from the cross-country analysis.

Of course, the effects of reforms on growth and inequality are not homogeneous, with the same reforms potentially entailing very different equity-efficiency trade-offs across countries and over time. And the reform indices efficiently summarize complex multi-faceted phenomena, such that there may be heterogeneity in the implications of a change in the reform index value. More generally, the indices may not measure quite what we would want them to measure. Finally, inequality is also famously difficult to measure systematically across countries and time. However, this methodology and data have been used extensively to study the implications of structural reform for growth, including by the IMF (2008). And the related questions of distribution are of critical importance, especially from a policy perspective. We therefore believe that it is important to use the best available macroeconomic data to look at the relation among reforms, distribution and growth.

We assemble a comprehensive dataset of reform indices, covering financial, institutional, and real reforms, updating the dataset put together by Ostry et al. (2009). Financial reforms include domestic banking and security market reforms, as well as external capital market liberalization. We consider broad institutional reforms to the legal framework as well as real sector reforms including trade reforms, network reforms, and labor market reforms. For inequality, we use data from the Standardized World Income Inequality Database, developed by Solt (2009), which is the best source for consistent data on inequality for a wide range of countries and for a long time-series - essential for the analysis undertaken here.

Our overall finding is that some structural reforms do tend to give rise to growth-equity tradeoffs. However, the fact that reforms increase inequality should not be viewed as a reason to abandon structural reforms or undo reforms that have been undertaken. The net effect of reforms on growth remains positive for most reforms indicators, even after considering the negative effect from increased inequality. We also find that the extent of the trade-off between growth and equity varies by reform type. A granular approach to the analysis is thus essential. We have chosen to include results for all the indices used in IMF (2008) and Ostry et al. (2009) to study growth, and to that added two measures (collective bargaining and rule of law) that seemed a priori interesting reform areas and for which we had data with broad country and time coverage. We transparently report all results irrespective of whether they are economically or statistically significant for a particular index and despite the fact that some indices are arguably more informative than others about the underlying reforms. ${ }^{2}$

We find that domestic financial deregulation, external capital market liberalization, and one of our two measures of current account reform entail trade-offs between equity and efficiency, with both growth and inequality increasing after reforms. We find that basic institutional reforms that strengthen the legal system and popular observance of the law tend to increase growth with no adverse effect on inequality. The results for our index of network reforms

\footnotetext{
${ }^{2}$ The only exception is the agriculture reform index which was included in IMF (2008) and Ostry et al. (2009) but for which we do not report results here; we find no significant effects on either growth or inequality for our broad sample-likely reflecting the relevance of this index mainly for developing countries (IMF, 2015).
} 
(which measures inter alia the degree of competition and liberalization in the electricity and telecoms sectors), as well as our measure of the decentralization of collective labor bargaining, are the weakest and least robust, potentially due to data limitations.

Each of these reform indicators has shortcomings as far as its ability to measure the marketorientation of policies, but if the goal is a cross-country study of the type we are undertaking, they nevertheless represent the best option available; and they are the very same data used by the IMF and other researchers in earlier studies of the growth effects of structural reforms. We further acknowledge that our measures of labor and product market reforms cover a particularly narrow range. Telecoms and electricity are but a small fraction of the economy, and this index covers important aspects of product market reform, such as openness to entry, imperfectly. Decentralization of collective bargaining arrangements is but one aspect of labor market deregulation and indeed is one that may not engender employment opportunities, given the potential for unions to internalize the adverse employment implications of excessive wage claims and thus deliver greater wage flexibility in response to shocks (Blanchard et al., 2013).

Nevertheless, we believe that the tenor of our results passes a basic smell test of plausibility. Financial and external capital market liberalization have been found in previous studies to increase inequality; growth effects from external financial liberalization have proved difficult to establish using macro data, unless capital flows are unbundled into more disaggregated components. Basic legal reforms are often found to exert important effects on longer-run growth and development (with little distributional impact). With respect to goods trade liberalization, there is a growing literature suggesting that the impact on inequality may undo some of the gains from trade (e.g., Antras et al., 2016, for the United states), and a more general sense that job displacement from trade may be very difficult to remedy in practicethat is to ensure that displaced workers actually are successfully retrained to find satisfying, well-paying alternative employment that restores the dignity they enjoyed in their previous jobs (Williams, 2016).

The policy message of our results is two-fold. First, structural reforms exert effects on both growth and equity. In a way, this is unsurprising, given that these reforms by their nature give a greater role to market forces in the economy and the market is in no way constrained to ensure that gains get equitably shared. More surprising is that economists so often ignore the distributional impact of structural reforms. This may be because the effects are seen as small, or because of a view that even large impacts can be easily remedied through appropriate design of the reforms or complementary policies. However, we find evidence that, on average, distributional effects of many reforms are significant and are not in fact remedied in practice.

Our paper is calling attention to the distributional effects because knowledge about their nature and magnitude is essential to give credibility to claims that coherent policy packages will be put in place to mitigate the adverse distributional impacts of reforms. Attention to these effects is warranted not only because equity is often an objective in its own right, nor even because distributional effects can directly undercut growth objectives being targeted by reform, but also because there is emerging evidence that support for supply-enhancing policies can be undercut by a failure to design policy packages to mitigate distributional effects (Colantone et al., 2015). 
Our second message is that distributional consequences of reform do not justify rolling back the clock and re-regulating economies or scaling down ambitious structural reform agendas. Indeed, to do so would impose severe costs on economies given that reforms, even taking into account distributional effects, engender large positive growth effects. This paper is thus not a mea culpa against advice to vigorously pursue supply-side reforms. Some claim that speaking about distributional consequences gives ammunition to the anti-reform camp. Our sense, however, is that credibility of policy advice will not be enhanced by sweeping distributional effects under the rug (Rodrik, 2011). Rather, the paper takes the view that reforms need to be designed with distributional consequences in mind, that reform packages should be put together that attempt to balance winners and losers across reforms, and that redistributive fiscal tools be employed to mitigate adverse distributional effects ex post (Box 1). This threepronged approach would improve growth-equity tradeoffs and restore faith in policy commitments that gains from reform will be broadly shared. ${ }^{3}$

The remainder of this paper is organized as follows. Section II below provides a brief review of the literature. Section III describes our data while IV discusses our methodology. Section V presents the results and section VI implements a simple calculation for the net effect of reforms on growth. Finally, section VII concludes.

\section{A REVIEW OF THE LITERATURE}

The relations among growth, inequality, and reforms have been the subject of a large literature. Most of the papers, however, focus on two of these variables at a time, with very few studies examining the effect of reforms on both growth and inequality.

A very large literature looks at the impact of structural reforms on growth and productivity, with much of it zeroing in on only a subset of the measures we consider in this paper. The consensus in this literature is that reforms can yield substantial growth dividends by promoting faster capital accumulation and/or improving resource allocation. Ostry et al. (2009) carries out an in-depth analysis of the impact of different reforms on economic growth and finds supportive evidence of pro-growth effects - using both panel growth regressions and an eventstudy approach. Many other studies focus on particular reform areas. The positive effect of trade liberalization on growth is documented in Sachs and Warner (1995), Krueger (1997), Frankel and Romer (1999), Berg and Krueger (2003), and Dollar and Kraay (2004). Levine $(1997,2005)$ provides an overview of the literature on financial development and growth, while Quinn and Toyoda (2008) study the impact of capital account liberalization. IMF (2016) focuses on product and labor market reforms in advanced countries rather than the broad country coverage of this paper, finding that reforms raise output in the medium term, but that short-term benefits may require complementary macroeconomic policies.

\footnotetext{
${ }^{3}$ Our conclusions in this respect are consonant with Fabrizio et al. (2016), which takes a methodologically very different approach to look at the nexus among structural reform, inequality, and growth. We view the two methodologies as complementary, insofar as they have very different strengths and weaknesses. The granularity of their approach permits country- and policy-specific analyses (including design of policy packages that can improve growth-equity tradeoffs) that are not possible under our broad macro frame. However, this makes it very hard to generalize and leaves one wanting to see the big picture, i.e., the patterns that emerge from the macro data and a more general assessment of the impact of past reforms. Our call for reform packages to be designed with distribution in mind motivates the use of country-specific tools of the type developed in their paper.
} 


\section{Box 1. Improving Growth-Equity Tradeoffs-Some Lessons from IMF Advice}

The general picture from the macroeconomic evidence in this paper is that many reforms engender growth-equity tradeoffs. This box takes these findings - and the corresponding conclusion that reforms need to be designed with distributional consequences in mind - as given, and asks whether IMF research and policy advice provide lessons about how to improve the equity-efficiency tradeoffs on the ground. A number of lessons can be gleaned about how to strengthen the growth effects of such reforms and mitigate their distributional impact, including the role of initial conditions, the appropriate sequencing of reforms, and accompanying polices that can make reform packages supportive of both growth and equality.

\section{Role of initial conditions and sequencing of reforms}

Steps to develop domestic financial institutions are an important precondition to garner the gains of capital account liberalization reforms both in terms of growth (Ostry and others, 2009; Kose 2011; IMF 2012) and equality (Furceri and Loungani, 2015). Similarly, fostering financial inclusion can increase growth - by providing greater access of firms and households to various banking services, affording businesses the resources to expand, and enhancing consumption-smoothing and investment - these can significantly reduce the negative distributional consequences of domestic financial deregulation (Fabrizio and others 2016).

Careful attention to the state of the business cycle is important in the context of labor market reforms. Many fiscal structural reforms in the labor market area - such as reduced labor tax wedges and increased public spending on active labor market policies - entail fiscal stimulus and thus have larger output and employment effects during periods of economic slack. Reforms to employment protection and unemployment benefit systems, in contrast, have contractionary effects in periods of weak demand. This may result in increased inequality, especially for unemployment benefit reforms (Duval and Furceri 2016). This suggests that product market reforms (whose effects do not depend on the cycle) and labor market reforms that entail fiscal stimulus should be prioritized in periods of economic slack. Other labor market reforms could be costly under weak economic conditions, and should be accompanied by supportive macroeconomic policies - including monetary and fiscal stimulus where space is available. Alternatively, they might be grandfathered - that is, applying new rules only to new beneficiaries - or be enacted but implemented when macroeconomic conditions are stronger.

\section{Accompanying policies}

Fiscal redistribution, carried out in a way that is consistent with macroeconomic efficiency, can help mitigate the distributional consequences of reforms without reducing growth (Ostry, Berg and Tsangarides, 2014). Fiscal policy already plays an important redistributive role in many advanced economies, but this role can be reinforced by greater reliance on wealth and property taxes, more progressive income taxation, and better targeting of social benefits (Bastagli and others 2012; Clements and others 2015). In addition, reducing tax expenditures that benefit high-income groups would reduce inequality and free budget resources for productive spending or cuts in marginal labor income taxes (OECD, 2015). In many emerging and developing economies, improved revenue mobilization together with well-targeted cash transfers and increased infrastructure spending would help reduce inequality while increasing growth. 
Continued...

"Trampoline" policies, including active labor market policies such as job counseling and retraining, are key to mitigate job displacement from trade and structural changes. These policies help people adjust faster to changes in the structure of the economy and to economic shocks, reducing unemployment spells and the resulting depreciation of skills and employability (Trebilcock, 2014). Hiring and wage subsidies can also be effective in boosting employment, particularly when targeted to workers for low-wage jobs and to youth (IMF, 2012).

Education policies are also important. In a world in which technological change is increasing productivity and simultaneously mechanizing jobs, raising skill levels is critical for reducing the dispersion of earnings. These policies can also help to improve the income prospects of future generations as educated individuals are better able to cope with technological and other changes. In advanced economies, with an already high share of secondary or tertiary graduates among the working-age population, policies that improve the quality of upper secondary or tertiary education would be important. In developing countries with currently low levels of education attainment, policies that promote more equal access to basic education could help reduce inequality by facilitating the accumulation of human capital, and making educational opportunities less dependent on socio-economic circumstances.

Finally, policies aimed at improving property rights, increasing labor mobility and addressing informality in many low-income and developing economies have the potential to enhance the payoffs of reforms while reducing their adverse distributional consequences. For example, in circumstances of limited financial access, financial reforms may increase inequality in these countries by benefiting mostly manufacturing and modern service sectors. In this context, policies aimed at fostering labor mobility - such as strengthening land rights, improving infrastructure, and providing accessible education to equip the labor force with the needed skills - would increase labor supply for the emerging manufacturing and services sectors, inducing an equalization of wages and reducing inter-sectoral inequality.

A second, perhaps smaller, strand of the literature looks at the effect of different structural reforms on inequality. Theory makes mixed predictions of the effect of financial development on inequality. Models in which the poor are disproportionally affected by credit constraints predict that financial development reduces inequality (Galor and Zeira, 1993). Other models, in which the rich have better access to the formal financial sector, predict that financial sector liberalization increases inequality (Greenwood and Jovanovic, 1990). Empirical results on the effect of financial development on inequality are also mixed (Classens and Perotti (2007) provides a review.) Clarke et al. (2006) and Beck et al. (2007) find that financial development reduces inequality but Roine et al. (2009), for example, finds that financial deepening increases inequality, i.e., financial deepening need not lead to financial inclusion. These studies typically use de-facto measures of financial development.

Jaumotte et al. (2013) and Furceri, Loungani and Ostry (2017) find that capital account liberalization increases inequality. Larrain (2015), using sectoral data for 20 advanced 
economies, finds that capital account openness increases wage inequality, particularly in industries with high financial dependence. Various mechanisms have been proposed to explain this result: opening up to FDI can increase the skill premium in developing countries by raising demand for skilled workers; opening up increases the likelihood of financial crisis and sudden stops; the rich may gain greater access to finance; the bargaining power of labor may fall; or governments may engage in a race to the bottom on tax rates (see also Ostry et al., 2016).

On current account restrictions, Heckscher-Ohlin theory suggests that inequality should decrease in low-income countries as they open up to trade, but empirical evidence usually does not match this prediction. A growing recent literature has proposed new mechanisms through which trade can increase inequality (within-industry effects; offshoring of tasks; diminished power of labor to negotiate higher wages): Harrison et al. (2010) provides a review.

There is also evidence that labor market reforms that reduce the bargaining power of workers can increase inequality, given the greater propensity for firm-level wages to reflect differential productivities. Relatedly, Jaumotte and Osorio Buitron (2015) find that lower unionization rates are associated with higher top earners' income shares.

Finally, a third strand of the literature looks at the relation between growth and inequality. There is growing evidence that suggests that high and rising inequality is associated with more fragile and lower levels of growth (Berg and Ostry, 2012; Ostry et al., 2014). To some degree, redistributive fiscal policies can ameliorate equity, with any cost to growth likely small at low initial levels of redistribution but rising if redistribution is already extensive.

\section{REFORMS DATA}

In order to study the equity-efficiency tradeoffs from structural reforms, we assemble a dataset with a large number of de-jure and survey-based reform indices spanning the financial and real sectors, and also covering the institutional setup of a country. Many of the reform indicators are updated versions of those used in Ostry et al. (2009). Appendix I provides details about each reform index, its country and time coverage, and source. Here we provide a brief description of the indices and look at their distribution over time and across countries.

For financial sector reforms, we use a measure of domestic financial liberalization that captures the degree of controls and competition in the banking system (extent of interest rate and credit controls, competition restrictions, and public ownership) as well as restrictions on the development of local securities markets (bonds and equities). Another financial sector reform we consider is an external capital account liberalization index. This variable is based on the methodology in Quinn (1997) and Quinn and Toyoda (2008), and draws on information contained in the text of the IMF's Annual Report for Exchange Arrangements and Exchange Restrictions (AREAER). It captures restrictions placed on financial transactions between residents and nonresidents, corresponding to inflow and outflow restrictions, respectively. It does not distinguish between different asset classes, i.e., FDI, portfolio flows, etc. ${ }^{4}$

\footnotetext{
${ }^{4}$ Disaggregated restrictions data were not reported in the AREARs before 1996. Jahan and Wang (2016) and Fernandez et al. (2015) present such data, but only for the period after 1996.
} 
To assess the impact of the institutional setting of a country on growth and inequality, we use data on the law and order index from the International Country Risk Guide (PRS Group). This index assesses the impartiality of the legal system and the popular observance of the law. We interpret this index to capture the effect of broad legal reforms which potentially increase economic freedoms and the enforceability of property rights. ${ }^{5}$

For real sector reforms, we focus on openness with respect to international trade and network reforms. We use two indices of openness to international trade. The first is a measure of tariff barriers. It is a weighted average tariff rate (based on most favored nation tariffs) normalized to lie between 0 and 1, with higher values of the index implying lower tariff levels (more openness). The second is a measure of non-tariff barriers to current account transactions as captured in the IMF's AREAER database. The index measures restrictions on the use of proceeds from current account transactions (e.g. surrender requirements) as well as restrictions on the underlying transactions themselves (e.g. license requirements for imports and exports) ${ }^{6}$ The network reforms index measures the extent of competition and quality of regulations in the telecommunications and electricity sectors.

For labor market reforms, we use an index that captures the extent of collective bargaining, with higher values of the index indicating less centralized bargaining systems, i.e., more liberalized labor markets. ${ }^{7}$ This index tries to capture the idea that higher levels of collective bargaining (lower values of the index) can reduce allocative efficiency by breaking the link between firm-level wages and marginal products. This index is taken from the World Economic Forum's (WEF) Global Competitiveness Report, and is based on surveys administered in different countries. We use data from the WEF as this is the only source for labor market reforms with wide country and time coverage. It is important to note, however, that the collective bargaining variable covers only one aspect of labor market reforms, ignoring other areas like hiring and firing restrictions, unemployment benefits, safety nets, etc. Furthermore, the cross-country comparability of the data might be limited due to the use of subjective surveys. Therefore, the results on labor market reforms should be interpreted with particular caution.

All indicators are rescaled to lie between zero and one. Higher values of the index imply more liberalized economies. Figure 1 plots the distribution of the reform indicators by income group. For each country, we take the average of each reform indicator between 2001 and 2005 and then report box-plot diagrams for advanced economies, middle-income countries (MICs), and low-income countries (LICs) for this average. ${ }^{8}$ The advanced economies have almost

\footnotetext{
${ }^{5}$ We use these ICRG data (like the WEF data described above) owing to their wide country and time coverage. Results need to be interpreted with caution as the cross-country comparability of the data might be limited.

${ }^{6}$ The index is not a comprehensive measure of non-tariff barriers as it does not capture sanctions, embargos and other non-tariff barriers not reported in the AREAERs. Quinn (1997) provides more details on the construction of the index. Prati et al. (2013) also use this index to measure the effect of trade openness on growth.

${ }^{7}$ While all the reforms indicators used in IMF (2008) and Ostry et al. (2009) are purely de-jure measures of reforms, the labor market and institutional reforms index are from other sources and are survey based.

${ }^{8}$ The World Bank's 2009 classification of countries into HICs, MICs and LICs is used. The group of advanced countries is based on the WEO definition and mainly excludes oil exporting HICs. Appendix III provides details.
} 
Figure 1. Box Plots of Reform Indices
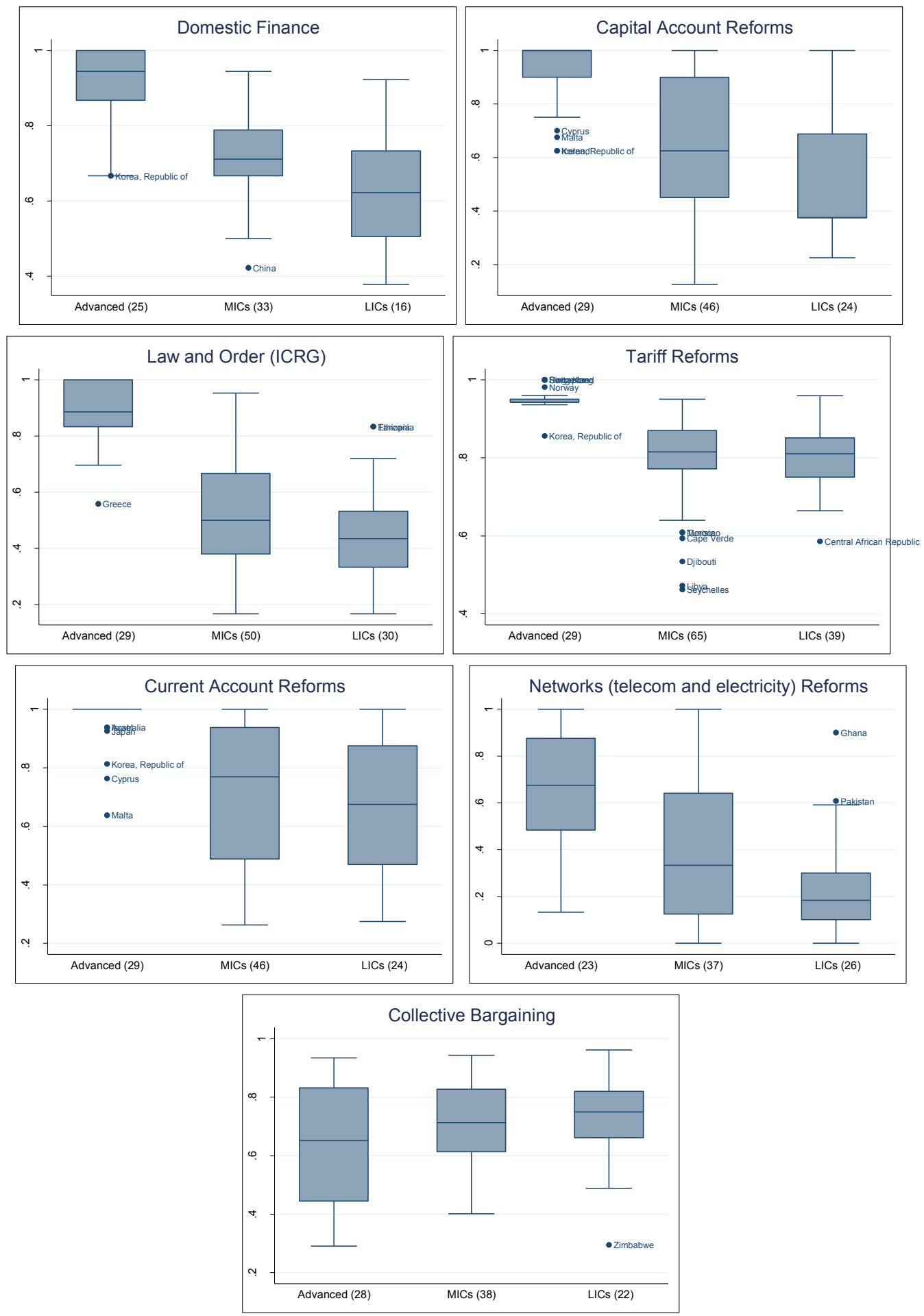

Notes: Appendix I provides details about source and description of different reform indices. Higher values of the index imply more liberalized economies. All indices rescaled to lie between 0 and 1 . Box-plots of the distribution of the reform indices for advanced economies, MICs and LICs (average of index between 2001 and 2005 for each country). The line inside the box is the median, the box gives the inter-quartile range (IQR), and the whiskers correspond to the most extreme values within 1.5 IQR of the nearer quartile. Outliers beyond 1.5 IQRs are plotted as points. Number of countries in each group for which data was available mentioned in brackets along the $x$-axis. 
completely reformed along the domestic finance, trade, capital account, and law and order dimensions with almost all advanced countries having an index greater than 0.8 . LICs and MICs lag behind advanced economies in these reform areas.

For networks and labor market reforms, the picture is blurrier. For the collective bargaining index, there is no clear difference between advanced economies and MICs and LICs. In fact, there is large variation in the index within advanced economies, reflecting the fact that different advanced economies follow very different labor market models. Nordic countries, for example, have relatively high levels of collective bargaining (low values of the index) while Anglo-Saxon countries have low levels of collective bargaining (high values of the index). The average value of the index for MICs is actually higher than for advanced economies (MICs have less collective bargaining on average than advanced economies). Similarly, for network reforms, there is considerable overlap in the distribution of the index between advanced countries and the other two groups.

Figure 2 plots the average level of the reform indicators by country group over time. There has been a broad trend toward liberalizing domestic finance, trade, capital accounts and network industries. However, the gap between advanced economies, MICs and LICs has been maintained throughout.

\section{Growth-Equity Trade-Offs: An Assessment Framework}

We use two different methodologies to assess the effect of reforms on growth and inequality. As a first step, we use standard regression models. We supplement these with a study of growth and inequality dynamics around large episodes or up-breaks in structural reforms. Beyond these two approaches, we look at a selection of country cases to enrich our sense of how the patterns thrown up by the cross-country empirical analysis reveal themselves in the narrative experience of countries following their implementation of structural reforms.

We exclude the transition economies from our sample as these countries went through a period of comprehensive reform following Communism's collapse, with the resulting very large increase in inequality related more to the wholesale transition to the market economy than to any particular structural reform.

\section{Regression Methodology}

To assess the growth-equity trade-offs from reforms, we run separate regressions with growth and inequality as dependent variables. We include our different structural reform variables on the RHS (one variable at a time). All regressions use five-year averaged data.

To assess the effect of reforms on growth, we use standard dynamic (convergence) growth regressions of the form

$$
\frac{y_{i, t}-y_{i, t-4}}{5}=\beta_{1} y_{i, t-4}+\gamma_{1} \overline{S R}_{i, t}^{j}+\gamma_{2} \overline{\operatorname{Ineq}}_{i, t}+\alpha_{1} \bar{X}_{i, t}+\mu_{i}+\mu_{t}+\epsilon_{i, t}
$$

where $y_{i, t}$ is the log of per capita GDP of country $i$ at time $t, \overline{S R}_{i, t}^{j}$ is the average of the structural reform indicator between time $t-4$ and $t, \overline{I n e q}_{i, t}$ is the level of inequality averaged between time $t-4$ and $t$, while $\bar{X}_{i, t}$ represents other controls also averaged between $t-4$ and $t$. 
Figure 2. Reform Indices Over Time by Income Level
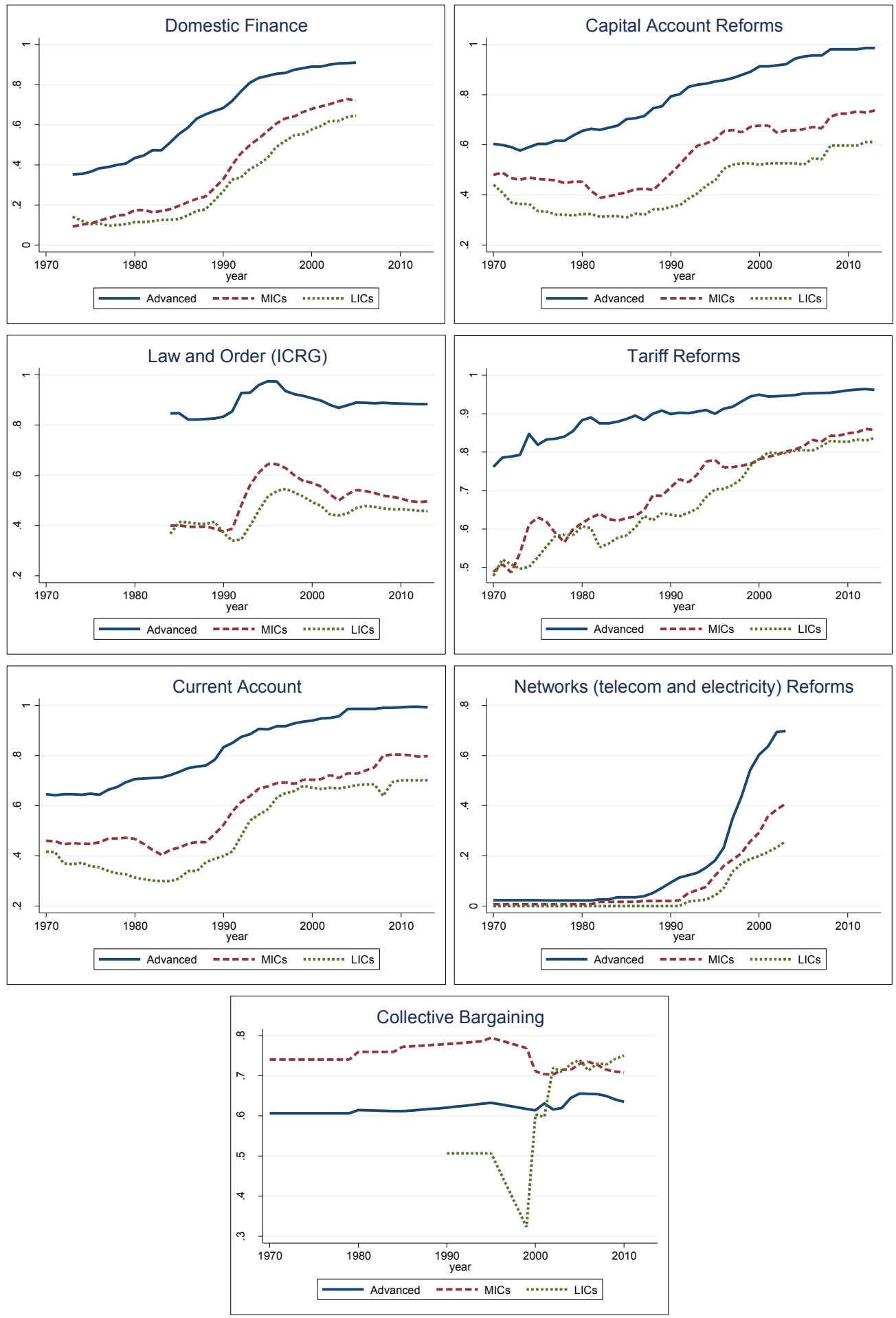

Notes: Appendix I provides details about source and description of different reform indices. Higher values of the index imply more liberalized economies. All indices rescaled to lie between 0 and 1 . Plots the average level of each reform index for each year for the group of advanced countries, MICs and LICs. Country coverage changes over time as more data becomes available. 
Following Ostry et al. (2014), in our baseline specification we include net inequality as a control variable. ${ }^{9}$ We do robustness checks in which log of investment and the log of total education are also included as controls. A negative value for $\beta_{1}$ implies convergence.

In this model, structural reforms (as well as the other $X$ variables) have a permanent effect on the level of per-capita income but no effect on long-run growth rates. Reforms lead to higher growth in the transition and eventually to a higher level of per-capita income in steady state. This is consistent with the neo-classical growth model where long-term growth depends only on the exogenous growth rate of productivity (captured by the time effects). The coefficient of interest is $\gamma_{1}$ which captures the direct impact effect of reform on growth.

Data on per capita GDP and investment are from the Penn World Tables 7.1 while total education is from Barro and Lee (2012). Inequality data is taken from SWIID 5.0 (Solt, 2009).

Analogous inequality convergence regressions are run to assess reforms' effects on inequality:

$$
\frac{\operatorname{gini}_{i, t}-\operatorname{gini}_{i, t-4}}{5}=\beta_{2} g i n i_{i, t-4}+\gamma_{3} \overline{S R}_{i, t}^{j}+\alpha_{2} \overline{g w t h}_{i, t}+\mu_{i}+\mu_{t}+\epsilon_{i, t}
$$

where gini $_{i, t}$ is the gini coefficient for market inequality of country $i$ at time $t, \overline{S R}_{i, t}^{j}$ is the average of the structural reform indicator between time $t-4$ and $t$, while $\overline{g w t h}_{i, t}$ is the averaged growth rate of per capita GDP (to allow for two-way causation between inequality and growth) between $t-4$ and $t .{ }^{10}$ The coefficient of interest is $\gamma_{3}$, as this tells us the impact effect of reforms on inequality. ${ }^{11}$ In this specification, reforms only affect the level of inequality in the steady state. However, the presence of lagged inequality on the RHS allows for dynamic effects, with reforms impacting the gini gradually over time. In the results reported below, we find that the coefficient $\beta_{2}$ is usually negative and significant, implying the presence of convergence dynamics. Other papers which have used a similar dynamic specification when studying inequality include Benabou (1996), Ravallion (2003), Banerjee and Duflo (2003), Beck, Demirguc-Kunt, Levine (2007), and Dreher and Gaston (2008).

\footnotetext{
${ }^{9}$ Net inequality measures inequality in income after taxes and transfers; it thus equals market inequality plus the effect of taxes and transfers. See for example Ostry et al. (2014) for details. We use net inequality as a control in the growth regression as the channels through which inequality affects growth (savings, human capital accumulation, political economy effects etc.) are likely to depend on net inequality rather than market inequality. Using market inequality in the regressions, however, makes little difference to the results.

${ }^{10}$ Note that we include the contemporaneous level of the structural reform and other control variables on the RHS but instrument these with lags to account for potential endogeneity. Using the reform index at the beginning of the period instead of the contemporaneous average yields broadly similar results for the inequality regressions, although the effect of reforms on growth is somewhat weaker.

${ }^{11}$ We conducted several robustness checks to this specification, including to test for Kuznets effects and control for technological progress, education and investment. As is common in the literature, we do not find evidence for a Kuznets curve in the data, i.e., the coefficients on the level of per-capita income and its square are insignificant (see e.g., Frazer, 2006). Furthermore, our results pertaining to the effects of reforms on inequality remain broadly similar when Kuznets-type effects are allowed for. Adding other control variables does not alter our main findings either, with only the effect of network reforms and collective bargaining being somewhat weaker.
} 
All regressions are estimated using system GMM to try and account for reverse causality, endogeneity, and dynamic panel bias. ${ }^{12} \mathrm{We}$ report the results of over-identification and autocorrelation tests as well as the number of instruments and groups (countries) in each regression. The regressions generally pass these diagnostics. Standard errors are clustered at the country level.

\section{Reform Episodes}

We complement the regression analysis with a look at how growth and inequality behave around large reform episodes. The cost of focusing only on the period around a reform break is that we use less of the variation in the data. ${ }^{13}$ However, this method is in some ways more transparent and simple. The emphasis on large events represents in effect an alternative identification strategy in which we assume, partly informed by the narrative, that these large reform episodes are not a function of future growth or inequality, and we do not need to make assumptions about the role of lagged values as instruments. The focus on large events also helps us to abstract from other factors that may be driving inequality and growth at the same time, and large shocks across reforms may be less correlated with each other. Of course, this identification strategy is not ironclad, as large reforms might get implemented in response to other economic developments and do not generally occur in isolation, but we view it as complementary to regressions because the weaknesses are different.

We first identify large reform breaks by using a simple algorithm which looks for large changes in the reform index in a three-year window. In addition, the algorithm checks to see that: (i) the reforms are not reversed within a five-year window; and (ii) the large change in the index is not starting from a temporary low point, i.e. there was no reform reversal in the three prior years which are now getting reversed again. If neither of the above conditions holds, then the algorithm identifies a break (more details of the algorithm can be found in Appendix II).

Having identified reform episodes, we look at the evolution of growth and inequality in the period five years before and after the identified breaks. ${ }^{14}$ In particular, we first residualize growth and inequality by taking residuals from regressions of growth and market inequality on

\footnotetext{
${ }^{12}$ While it is natural to use system GMM techniques to estimate dynamic panel regressions, we also checked for robustness by estimating pooled OLS as well as fixed effect regressions. The results for the effects of reform on growth are similar irrespective of the estimation method. For the inequality regression, pooled OLS gives broadly similar results to system GMM while the results are usually weaker for fixed effects, suggesting that cross-country variation is important for identifying the reform-inequality relation.

${ }^{13} \mathrm{We}$ view this event study analysis as illustrative and therefore keep our methodology very simple and transparent. A thorough statistical assessment would require a more formal and sophisticated approach (such as local projection methods) which we do not undertake here.

${ }^{14}$ The trends look broadly similar when extending the time horizon to eight years after the reform episode.
} 
country- and time- fixed effects. We then take the average of the residualized measures (by years from break) across all countries for which we found a break. ${ }^{15}$

\section{Growth-Equity Trade-OfFS in Reforms: Results}

In this section, we present our main results regarding the effects of reforms on growth and inequality. The section comprises sub-sections on each of the main reform categories. In addition, the last sub-section looks at a number of country cases to illustrate the empirical findings with narrative histories of selected major structural reform episodes.

\section{A. Domestic Finance Reforms}

First, we consider reforms to the domestic financial system. Table 1 reports the regression results for the entire sample and for the sub-sample of LICs and MICs only. The first column reports the results for the growth regression with only net inequality as a control. The coefficient on the domestic financial reform indicator is positive and significant, implying that reforming the financial market boosts growth. To get a sense of economic magnitude, the row "Effect of Reform (75-50 percentile)" in Table 1 reports the long run effect on per capita GDP of moving the reform indicator from the median (Egypt or the Philippines in 2005) to the $75^{\text {th }}$ percentile (South Africa or Germany in 2015). Such a reform would increase per capita GDP by 35 percent. ${ }^{16}$ Column 2 of Table 1 repeats the growth regression but includes investment and total human capital as additional controls. The domestic finance reforms index continues being positive and highly significant. ${ }^{17}$ Also note that, echoing the result of Ostry et al. (2014), we find that an increase in inequality reduces growth.

Column 3 reports results for the inequality regression (equation 2). The coefficient on the domestic finance variable is again positive (and significant at the 10 percent level), indicating that domestic financial reforms also increase inequality. As the row "Effect of Reform (7550 percentile)" shows, an increase in the reform index from the median to the $75^{\text {th }}$ percentile raises market inequality by 1.57 gini points in the long run. Columns 4 to 6 repeat the regressions from column 1 to 3 but for the restricted sample of LICs and MICs only. Again, we find evidence for the positive growth effect of financial reforms. Furthermore, financial reforms have an even larger effect on inequality in LICs and MICs.

\footnotetext{
${ }^{15}$ We take the year before the break and average residualized growth and inequality across all countries for which breaks were identified. We do the same for 2 years before the break, the year after the break and so on. Note that, as different countries saw breaks at different times, we in effect are averaging over different calendar years, i.e., averaging by years from break rather than by calendar year. However, as we residualize growth and inequality, this does not result in a bias arising from common time trends, etc.

${ }^{16}$ The long run is defined throughout the paper as the change in per-capita GDP or inequality 50 years after the reform. From the regression results, $\frac{\left(1-\left(1+\beta_{1}\right)^{50}\right) \gamma_{1} \Delta S R}{-\beta_{1}}$ gives the 50-year increase in log of per-capita GDP when the reform index changes by $\Delta S R$. The percent increase in per-capita GDP is $\exp \left(\frac{\left(1-\left(1+\beta_{1}\right)^{50}\right) \gamma_{1} \Delta S R}{-\beta_{1}}\right)-1$.

${ }^{17}$ The benefits of financial development can be non-monotonic, diminishing (or even becoming negative) at high levels of financial deepening. Our de-jure measures of reforms are generally not well suited for picking up such non-linear effects as they do not capture extreme cases but rather identify basic reforms.
} 
Theoretically, the effect of domestic financial reforms on inequality is ambiguous. Reforms could reduce credit constraints, lead to greater financial inclusion, and thus reduce inequality (Galor and Zeira, 1993). On the other hand, if the rich have better access to the formal financial sector, further financial deepening could benefit them disproportionately (Greenwood and Jovanovic, 1990). Our empirical evidence suggests that the latter force dominates.

Figure 3 shows the results from the reforms breaks/episodes analysis. The left panel plots the reforms index (red line and right axis) and residualized growth (blue line and left axis) for five years before and after the identified breaks. The right panel plots residualized inequality (blue line and left axis) and the reform index. There seems to be an increase in growth and inequality following a reform break, which mirrors the results we found using regression analysis. Overall, there is evidence of a trade-off between growth and equity arising from financial sector reforms. Reforms raise growth but also increase inequality.

\begin{tabular}{|c|c|c|c|c|c|c|}
\hline VARIABLES & $\begin{array}{c}\text { (1) } \\
\text { Growth } \\
\text { All Ctrys }\end{array}$ & $\begin{array}{c}\text { (2) } \\
\text { Growth } \\
\text { All Ctrys }\end{array}$ & $\begin{array}{c}\text { (3) } \\
\text { Inequality } \\
\text { All Ctrys }\end{array}$ & $\begin{array}{c}\text { (4) } \\
\text { Growth } \\
\text { LIC\&MIC }\end{array}$ & $\begin{array}{c}\text { (5) } \\
\text { Growth } \\
\text { LIC\&MIC }\end{array}$ & $\begin{array}{c}\text { (6) } \\
\text { Inequality } \\
\text { LIC\&MIC }\end{array}$ \\
\hline Domestic Finance & $\begin{array}{c}0.0630 * * * \\
(0.0146)\end{array}$ & $\begin{array}{c}0.0478 * * * \\
(0.0149)\end{array}$ & $\begin{array}{l}0.0065^{*} \\
(0.0038)\end{array}$ & $\begin{array}{c}0.0633^{* *} \\
(0.0261)\end{array}$ & $\begin{array}{c}0.0210 \\
(0.0263)\end{array}$ & $\begin{array}{c}0.0137 * * \\
(0.0058)\end{array}$ \\
\hline Net inequality & $\begin{array}{c}-0.1505 * * * \\
(0.0527)\end{array}$ & $\begin{array}{c}-0.0782^{*} \\
(0.0425)\end{array}$ & & $\begin{array}{c}-0.1940 * * \\
(0.0911)\end{array}$ & $\begin{array}{c}-0.0042 \\
(0.0909)\end{array}$ & \\
\hline Log(Investment) & & $\begin{array}{c}0.0410^{* * *} \\
(0.0125)\end{array}$ & & & $\begin{array}{c}0.0551^{* * *} * \\
(0.0089)\end{array}$ & \\
\hline Log(Education) & & $\begin{array}{c}0.0004 \\
(0.0085)\end{array}$ & & & $\begin{array}{c}0.0143 \\
(0.0171)\end{array}$ & \\
\hline Lagged pc GDP & $\begin{array}{c}-0.0126 * * * \\
(0.0037)\end{array}$ & $\begin{array}{c}-0.0129 * * * \\
(0.0037)\end{array}$ & & $\begin{array}{l}-0.0130 * \\
(0.0072)\end{array}$ & $\begin{array}{c}-0.0197^{* *} \\
(0.0093)\end{array}$ & \\
\hline Growth of pc GDP & & & $\begin{array}{c}-0.0378 \\
(0.0234)\end{array}$ & & & $\begin{array}{l}-0.0128 \\
(0.0402)\end{array}$ \\
\hline Lagged inequality & & & $\begin{array}{c}-0.0484^{* * *} \\
(0.0147)\end{array}$ & & & $\begin{array}{l}-0.0482 \\
(0.0343)\end{array}$ \\
\hline Effect of Reform (75-50 percentile) & 0.35 & 0.25 & 1.57 & 0.35 & 0.09 & 3.32 \\
\hline Observations & 444 & 427 & 392 & 271 & 254 & 225 \\
\hline No. of Countries & 74 & 70 & 74 & 49 & 45 & 49 \\
\hline No. of Instruments & 65 & 63 & 65 & 36 & 63 & 37 \\
\hline AR2 & 0.237 & 0.344 & 0.230 & 0.0567 & 0.365 & 0.133 \\
\hline Hansen & 0.450 & 0.393 & 0.319 & 0.310 & 0.988 & 0.234 \\
\hline $\begin{array}{l}\text { Notes: Data on per capita GDP growth and inves } \\
\text { SWIID 5.0. Details of reform variable in Appendi } \\
\text { the growth regression. Column } 3 \text { reports results } \\
\text { repeat the same regressions but for the restricte } \\
\text { (in gini points) in the long run ( } 30 \text { years) of movi } \\
\text { Estimation done using system GMM. P-value of } \\
p<0.05,{ }^{*} p<0.1\end{array}$ & $\begin{array}{l}\text { ent from Penn WC } \\
\text { First column repo } \\
\text { the dynamic inee } \\
\text { sample of LICs and } \\
\text { the reform index } f \\
\text { nsen and AR2 test }\end{array}$ & $\begin{array}{l}\text { Id Tables 7.1. Tot } \\
\text { ts results of a stan } \\
\text { uality regression (e } \\
\text { MICs only. Row "E } \\
\text { om the median to } \\
\text { eported. Robust s }\end{array}$ & $\begin{array}{l}\text { I education from } \\
\text { dard growth regre } \\
\text { quation 2) with ch } \\
\text { fect of Reforms" } r \\
\text { the } 75 \text { th percentil } \\
\text { andard errors clus }\end{array}$ & $\begin{array}{l}\text { rro and Lee (201) } \\
\text { on (equation } 1) \\
\text { ge in market in } \\
\text { orts the effect } \\
\text { All regressions } \\
\text { red at country I }\end{array}$ & $\begin{array}{l}\text { Net and market } \\
\text { olumn } 2 \text { adds add } \\
\text { uality on the LHS. } \\
\text { pc GDP (in perce } \\
\text { lude country and } \\
\text { el in brackets. ** }\end{array}$ & $\begin{array}{l}\text { equality from } \\
\text { ional controls to } \\
\text { olumns } 4 \text { to } 6 \\
\text { ) and inequality } \\
\text { me fixed effects. } \\
\\
><0.01, * *\end{array}$ \\
\hline
\end{tabular}

Table 2 reports the results for the growth and inequality regressions for the sub-components of the financial reforms variable. The financial reform variable is composed of two subcomponents: for the securities market (one sixth weight) and for banking (five sixths weight), respectively. The table reports the coefficients of these reform variables separately as well as in the aggregate. Both the banking and the securities market components boost growth and inequality, especially in LICs and MICs. 
Table 2. Subcomponents of Domestic Finance Reforms Index: Growth-Equity Trade-off

\begin{tabular}{lcc|cc}
\hline & \multicolumn{2}{c|}{ All Countries } & \multicolumn{2}{c}{ LICs \& MICs } \\
& Growth & Inequality & Growth & Inequality \\
\hline \multirow{2}{*}{ Domestic Finance--Overall } & $0.0630^{* * *}$ & $0.0065^{*}$ & $0.0633^{* *}$ & $0.0137^{* *}$ \\
& $(0.0146)$ & $(0.0038)$ & $(0.0261)$ & $(0.0058)$ \\
Securities Market & $0.0339^{* * *}$ & 0.0027 & $0.0534^{* *}$ & $0.0073^{* *}$ \\
& $(0.0109)$ & $(0.0025)$ & $(0.0244)$ & $(0.0029)$ \\
Banking & $0.0446^{* * *}$ & 0.0057 & $0.0487^{* *}$ & $0.0096^{*}$ \\
& $(0.0144)$ & $(0.0040)$ & $(0.0220)$ & $(0.0050)$ \\
\hline
\end{tabular}

Notes: Data on per capita GDP growth from Penn World Tables 7.1. Net and market inequality from SWIID 5.0. Details of reform variable in Appendix I. Table reports results for the subcomponents of the domestic finance reform index. First column reports results of a standard growth regression (equation 1) with lagged pc GDP and net inequality as controls. Column 2 reports results for the dynamic inequality regression (equation 2 ) with change in market inequality on the LHS and lagged inequality and pc GDP growth as controls. Column 3 and 4 repeat the same regressions but for the restricted sample of LICs and MICs only. Only the coefficient on the reform indicator is reported. All regressions include country and time fixed effects. Estimation done using system GMM. Robust standard errors clustered at country level in brackets. ${ }^{* * *} p<0.01, * * p<0.05, * p<0.1$

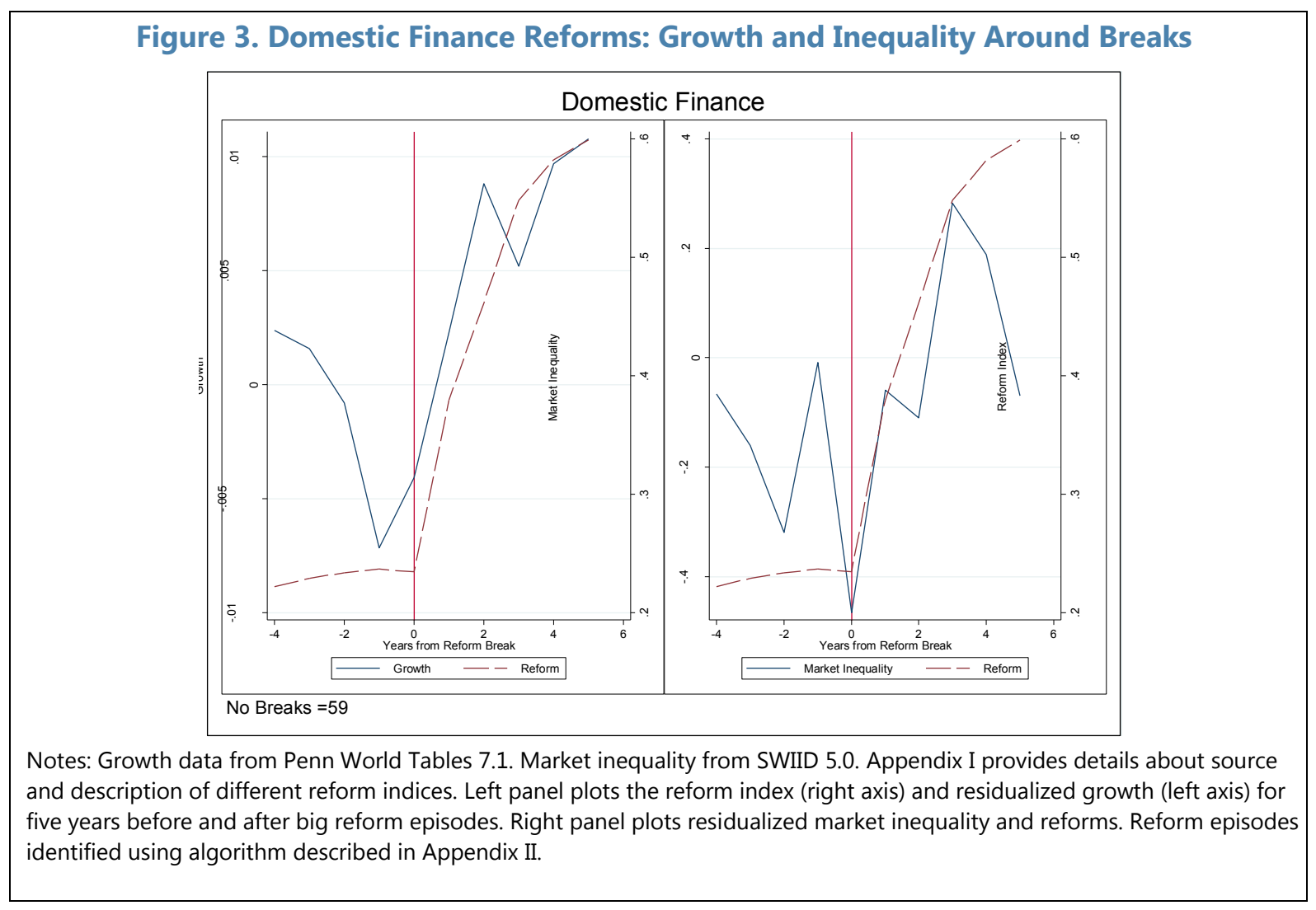

CInternational Monetary Fund. Not for Redistribution 


\section{B. Capital Account Liberalization}

Table 3 reports the regression results for the capital account liberalization index. For the growth regression (column 1), the coefficient on the capital account indicator is positive but marginally insignificant at the 10 percent level (t-stat of 1.6), implying that opening up the capital account has an uncertain and apparently modest growth benefit. Furthermore, the growth results are weaker when we include other controls in column 2 . For the inequality regression (column 3), the coefficient on capital account liberalization index is positive and significant. For the restricted sample of LICs and MICs only, there does not seem to be a clear growth benefit from liberalizing capital account restrictions, but there is an increase in inequality. In LICs and MICs, moving the index from the median (Kenya or Philippines in 2005 ) to the $75^{\text {th }}$ percentile (US or any other fully liberalized economy on this dimension) increases inequality by 2.62 gini points. Figure 4 shows the results from the reforms breaks/episodes analysis. The graphs suggest an increase in growth and inequality following big episodes of capital account liberalization.

The effect of external financial liberalization on growth and inequality probably depends crucially on the mix of capital flows. FDI is more likely to boost growth, but can also increase inequality by raising skill premiums. Short-term debt flows on the other hand may increase the chances of sudden stops and financial crises, potentially harming growth on average while also perhaps raising inequality. Our empirical evidence shows that, on balance, there is some evidence of trade-offs between growth and equity, with capital accounts liberalization increasing inequality, and possibly having modest effects on growth. ${ }^{18}$

\section{Rule of Law}

Table 4 reports results for the rule of law reform indicator. Improving the quality of the legal system is very beneficial for growth. The coefficient of the indicator is positive and significant when considering all countries (column 1) as well as when restricting to LICs and MICs (column 4). An increase in the reform index from the median (Vietnam in 2005) to the $75^{\text {th }}$ percentile (Portugal or Japan in 2005) results in an impact effect on growth of almost 0.6 percent, while in the long run per-capita GDP increases by 39 percent. Furthermore, reforming the legal system seems to have no effect on inequality, with the coefficient always being insignificant (with t-stats less than 1) in the inequality regressions.

Overall, legal sector reforms seem to generate no trade-offs, with reforms being good for growth but at the same time not increasing inequality. These reforms probably improve the enforceability of property rights while at the same time creating a level playing field for all, thus increasing growth without contributing to adverse distributional effects. From a policy perspective, some caution is nonetheless warranted: ours is a de facto measure-i.e. subjective survey-based measure of perception of rule of law - and its connection to specific reforms is not obvious.

\footnotetext{
${ }^{18}$ Unfortunately, we cannot test the hypothesis that different types of asset flows have different equity-efficiency trade-offs as long time-series for the capital account liberalization index by asset category are not available.
} 
Table 3. Capital Account Liberalization: Growth-Equity Trade-off

\begin{tabular}{|c|c|c|c|c|c|c|}
\hline VARIABLES & $\begin{array}{c}\text { (1) } \\
\text { Growth } \\
\text { All Ctrys }\end{array}$ & $\begin{array}{c}\text { (2) } \\
\text { Growth } \\
\text { All Ctrys }\end{array}$ & $\begin{array}{c}(3) \\
\text { Inequality } \\
\text { All Ctrys }\end{array}$ & $\begin{array}{c}\text { (4) } \\
\text { Growth } \\
\text { LIC\&MIC }\end{array}$ & $\begin{array}{c}\text { (5) } \\
\text { Growth } \\
\text { LIC\&MIC }\end{array}$ & $\begin{array}{c}(6) \\
\text { Inequality } \\
\text { LIC\&MIC }\end{array}$ \\
\hline Capital Account Restrictions & $\begin{array}{c}0.0181 \\
(0.0113)\end{array}$ & $\begin{array}{c}0.0144 \\
(0.0103)\end{array}$ & $\begin{array}{c}0.0075^{* * *} \\
(0.0027)\end{array}$ & $\begin{array}{c}-0.0001 \\
(0.0098)\end{array}$ & $\begin{array}{l}-0.0035 \\
(0.0094)\end{array}$ & $\begin{array}{c}0.0065 * * \\
(0.0030)\end{array}$ \\
\hline Net inequality & $\begin{array}{c}-0.1957 * * * \\
(0.0541)\end{array}$ & $\begin{array}{c}-0.0979 * * * \\
(0.0357)\end{array}$ & & $\begin{array}{c}-0.0988^{*} \\
(0.0591)\end{array}$ & $\begin{array}{c}-0.0408 \\
(0.0676)\end{array}$ & \\
\hline Log(Investment) & & $\begin{array}{c}0.0348^{* * *} \\
(0.0087)\end{array}$ & & & $\begin{array}{c}0.0308^{* *} \\
(0.0133)\end{array}$ & \\
\hline Log(Education) & & $\begin{array}{l}-0.0064 \\
(0.0069)\end{array}$ & & & $\begin{array}{l}-0.0101 \\
(0.0121)\end{array}$ & \\
\hline Lagged pc GDP & $\begin{array}{c}-0.0087^{* *} \\
(0.0037)\end{array}$ & $\begin{array}{c}-0.0088^{* * *} \\
(0.0029)\end{array}$ & & $\begin{array}{l}-0.0047 \\
(0.0057)\end{array}$ & $\begin{array}{c}-0.0057 \\
(0.0051)\end{array}$ & \\
\hline Growth of pc GDP & & & $\begin{array}{c}-0.0271 \\
(0.0229)\end{array}$ & & & $\begin{array}{c}0.0232 \\
(0.0239)\end{array}$ \\
\hline Lagged inequality & & & $\begin{array}{c}-0.0436 * * * \\
(0.0159)\end{array}$ & & & $\begin{array}{c}-0.0592 * * * \\
(0.0202)\end{array}$ \\
\hline Effect of Reform (75-50 percentile) & 0.20 & 0.16 & 3.84 & 0.00 & -0.03 & 2.62 \\
\hline Observations & 741 & 714 & 589 & 458 & 432 & 348 \\
\hline No. of Countries & 100 & 93 & 96 & 68 & 62 & 65 \\
\hline No. of Instruments & 61 & 103 & 57 & 61 & 101 & 55 \\
\hline AR2 & 0.135 & 0.214 & 0.804 & 0.140 & 0.204 & 0.743 \\
\hline Hansen & 0.139 & 0.632 & 0.561 & 0.624 & 1 & 0.625 \\
\hline \multicolumn{7}{|c|}{$\begin{array}{l}\text { Notes: Data on per capita GDP growth and investment from Penn World Tables 7.1. Total education from Barro and Lee (2012). Net and market inequality from } \\
\text { SWIID 5.0. Details of reform variable in Appendix I. First column reports results of a standard growth regression (equation 1). Column } 2 \text { adds additional controls to } \\
\text { the growth regression. Column } 3 \text { reports results for the dynamic inequality regression (equation } 2 \text { 2) with change in market inequality on the LHS. Columns } 4 \text { to } 6 \\
\text { repeat the same regressions but for the restricted sample of LICs and MICs only. Row "Effect of Reforms" reports the effect on pc GDP (in percent) and inequality } \\
\text { (in gini points) in the long run (30 years) of moving the reform index from the median to the } 75 \text { th percentile. All regressions include country and time fixed effects. } \\
\text { Estimation done using system GMM. P-value of Hansen and AR2 test reported. Robust standard errors clustered at country level in brackets. *** p<0.01, ** } \\
\text { p<0.05, * p }<0.1\end{array}$} \\
\hline
\end{tabular}

Figure 4. Capital Account Liberalization: Growth and Inequality Around Breaks

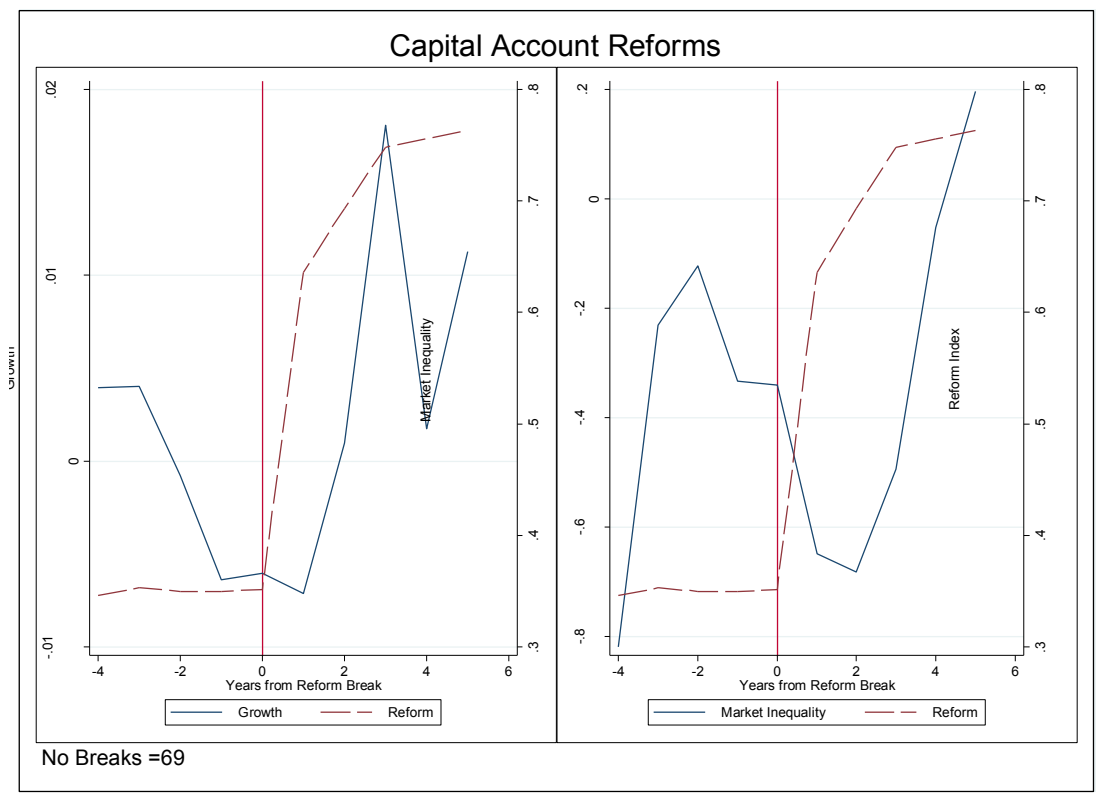

Notes: Growth data from Penn World Tables 7.1. Market inequality from SWIID 5.0. Appendix I provides details about source and description of different reform indices. Left panel plots the reform index (right axis) and residualized growth (left axis) for five years before and after big reform episodes. Right panel plots residualized market inequality and reforms. Reform episodes identified using algorithm described in Appendix II. 
Table 4. Law and Order: Growth-Equity Trade-offs

\begin{tabular}{|c|c|c|c|c|c|c|}
\hline VARIABLES & $\begin{array}{c}\text { (1) } \\
\text { Growth } \\
\text { All Ctrys }\end{array}$ & $\begin{array}{c}\text { (2) } \\
\text { Growth } \\
\text { All Ctrys }\end{array}$ & $\begin{array}{c}\text { (3) } \\
\text { Inequality } \\
\text { All Ctrys }\end{array}$ & $\begin{array}{c}\text { (4) } \\
\text { Growth } \\
\text { LIC\&MIC }\end{array}$ & $\begin{array}{c}\text { (5) } \\
\text { Growth } \\
\text { LIC\&MIC }\end{array}$ & $\begin{array}{c}(6) \\
\text { Inequality } \\
\text { LIC\&MIC }\end{array}$ \\
\hline Law and Order (ICRG) & $\begin{array}{c}0.0474 * * \\
(0.0225)\end{array}$ & $\begin{array}{l}0.0361^{*} \\
(0.0189)\end{array}$ & $\begin{array}{c}0.0043 \\
(0.0043)\end{array}$ & $\begin{array}{c}0.0622^{* * *} \\
(0.0215)\end{array}$ & $\begin{array}{c}0.0462^{* *} \\
(0.0185)\end{array}$ & $\begin{array}{c}0.0023 \\
(0.0067)\end{array}$ \\
\hline Net inequality & $\begin{array}{l}-0.0918 \\
(0.0988)\end{array}$ & $\begin{array}{l}-0.0540 \\
(0.0516)\end{array}$ & & $\begin{array}{c}0.0187 \\
(0.1021)\end{array}$ & $\begin{array}{c}-0.0143 \\
(0.0455)\end{array}$ & \\
\hline Log(Investment) & & $\begin{array}{l}0.0161^{*} \\
(0.0095)\end{array}$ & & & $\begin{array}{c}0.0157^{* *} \\
(0.0065)\end{array}$ & \\
\hline Log(Education) & & $\begin{array}{c}0.0177 \\
(0.0116)\end{array}$ & & & $\begin{array}{c}0.0110 \\
(0.0112)\end{array}$ & \\
\hline Lagged pc GDP & $\begin{array}{c}-0.0080 * * * \\
(0.0025)\end{array}$ & $\begin{array}{c}-0.0133 * * * \\
(0.0036)\end{array}$ & & $\begin{array}{c}-0.0033 \\
(0.0042)\end{array}$ & $\begin{array}{l}-0.0078 \\
(0.0048)\end{array}$ & \\
\hline Growth of pc GDP & & & $\begin{array}{c}-0.0761^{* * *} \\
(0.0261)\end{array}$ & & & $\begin{array}{l}-0.0114 \\
(0.0404)\end{array}$ \\
\hline Lagged inequality & & & $\begin{array}{c}-0.0340 * * \\
(0.0170)\end{array}$ & & & $\begin{array}{c}-0.0232 \\
(0.0164)\end{array}$ \\
\hline Effect of Reform (75-50 percentile) & 0.39 & 0.25 & 1.73 & 0.61 & 0.38 & 1.14 \\
\hline Observations & 471 & 435 & 426 & 324 & 289 & 283 \\
\hline No. of Countries & 108 & 97 & 104 & 77 & 67 & 74 \\
\hline No. of Instruments & 43 & 64 & 43 & 43 & 79 & 43 \\
\hline AR2 & 0.990 & 0.653 & 0.286 & 0.995 & 0.448 & 0.872 \\
\hline Hansen & 0.0216 & 0.0545 & 0.593 & 0.568 & 0.818 & 0.334 \\
\hline \multicolumn{7}{|c|}{ 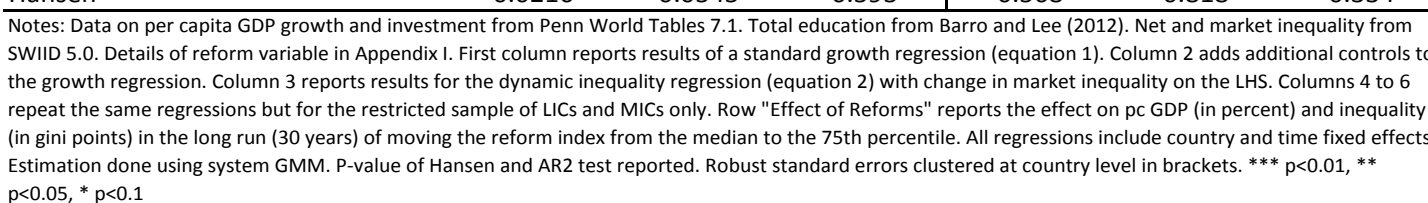 } \\
\hline
\end{tabular}

Table 5. Tariff Liberalization: Growth-Equity Trade-off

\begin{tabular}{|c|c|c|c|c|c|c|}
\hline VARIABLES & $\begin{array}{c}\text { (1) } \\
\text { Growth } \\
\text { All Ctrys }\end{array}$ & $\begin{array}{c}\text { (2) } \\
\text { Growth } \\
\text { All Ctrys }\end{array}$ & $\begin{array}{c}\text { (3) } \\
\text { Inequality } \\
\text { All Ctrys } \\
\end{array}$ & $\begin{array}{c}\text { (4) } \\
\text { Growth } \\
\text { LIC\&MIC }\end{array}$ & $\begin{array}{c}\text { (5) } \\
\text { Growth } \\
\text { LIC\&MIC }\end{array}$ & $\begin{array}{c}\text { (6) } \\
\text { Inequality } \\
\text { LIC\&MIC }\end{array}$ \\
\hline Tariff Reform & $\begin{array}{c}0.0385^{* *} \\
(0.0158)\end{array}$ & $\begin{array}{c}0.0395^{* *} \\
(0.0167)\end{array}$ & $\begin{array}{c}0.0004 \\
(0.0040)\end{array}$ & $\begin{array}{c}0.0198 \\
(0.0164)\end{array}$ & $\begin{array}{l}0.0352 * \\
(0.0197)\end{array}$ & $\begin{array}{c}0.0041 \\
(0.0061)\end{array}$ \\
\hline Net inequality & $\begin{array}{c}-0.1311^{* *} \\
(0.0536)\end{array}$ & $\begin{array}{c}-0.1059 * * * \\
(0.0394)\end{array}$ & & $\begin{array}{c}-0.0770^{*} \\
(0.0438)\end{array}$ & $\begin{array}{c}-0.0492 \\
(0.0422)\end{array}$ & \\
\hline Log(Investment) & & $\begin{array}{c}0.0410 * * * \\
(0.0071)\end{array}$ & & & $\begin{array}{c}0.0265^{* * *} \\
(0.0083)\end{array}$ & \\
\hline Log(Education) & & $\begin{array}{c}-0.0063 \\
(0.0087)\end{array}$ & & & $\begin{array}{c}0.0163 \\
(0.0110)\end{array}$ & \\
\hline Lagged pc GDP & $\begin{array}{c}-0.0052 * \\
(0.0027)\end{array}$ & $\begin{array}{l}-0.0054 * \\
(0.0030)\end{array}$ & & $\begin{array}{c}0.0012 \\
(0.0036)\end{array}$ & $\begin{array}{c}-0.0088^{* *} \\
(0.0043)\end{array}$ & \\
\hline Growth of pc GDP & & & $\begin{array}{l}-0.0383 * \\
(0.0222)\end{array}$ & & & $\begin{array}{c}-0.0040 \\
(0.0177)\end{array}$ \\
\hline Lagged inequality & & & $\begin{array}{c}-0.0172 \\
(0.0155)\end{array}$ & & & $\begin{array}{c}-0.0271 \\
(0.0169)\end{array}$ \\
\hline Effect of Reform (75-50 percentile) & 0.15 & 0.16 & 0.19 & NA & 0.13 & 1.26 \\
\hline Observations & 685 & 635 & 601 & 467 & 418 & 392 \\
\hline No. of Countries & 130 & 112 & 123 & 98 & 81 & 92 \\
\hline No. of Instruments & 81 & 97 & 89 & 89 & 81 & 89 \\
\hline AR2 & 0.262 & 0.876 & 0.997 & 0.166 & 0.491 & 0.849 \\
\hline Hansen & 0.327 & 0.116 & 0.612 & 0.614 & 0.243 & 0.890 \\
\hline $\begin{array}{l}\text { Notes: Data on per capita GDP growth and inves } \\
\text { inequality from SWIID 5.O. Details of reform vari } \\
\text { Column } 2 \text { adds additional controls to the growth } \\
\text { change in market inequality on the LHS. Columns } \\
\text { "Effect of Reforms" reports the effect on pc GDP } \\
\text { from the median to the } 75 \text { th percentile. All regre } \\
\text { Hansen and AR2 test reported. Robust standard }\end{array}$ & $\begin{array}{l}\text { nt from Penn W } \\
\text { in Appendix I. } \\
\text { ression. Columr } \\
\text { o } 6 \text { repeat the s } \\
\text { percent) and in } \\
\text { ons include cour } \\
\text { ors clustered at }\end{array}$ & $\begin{array}{l}\text { Vorld Tables } 7.1 . \\
\text { First column repc } \\
n 3 \text { reports result } \\
\text { same regressions } \\
\text { lequality (in gini } \\
\text { ntry and time fixe } \\
\text { country level in }\end{array}$ & $\begin{array}{l}\text { Total education } \\
\text { orts results of a } \\
\text { ts for the dynam } \\
\text { s but for the rest } \\
\text { points) in the lor } \\
\text { ed effects. Estim } \\
\text { brackets. }{ }^{* * *} \text { p }\end{array}$ & $\begin{array}{l}\text { from Barro and } \\
\text { tandard growt| } \\
\text { c inequality re } \\
\text { icted sample o } \\
\text { g run ( } 30 \text { years } \\
\text { tion done usin } \\
.01, * * p<0.05\end{array}$ & $\begin{array}{l}\text { Lee (2012). Net } \\
\text { h regression (eq } \\
\text { gression (equatic } \\
\text { if LICs and MICs } \\
\text { ) of moving the } \\
\text { g system GMM. } \\
{ }^{*} \text { p }<0.1\end{array}$ & $\begin{array}{l}\text { and market } \\
\text { ation 1). } \\
\text { n 2) with } \\
\text { only. Row } \\
\text { eform index } \\
\text { P-value of }\end{array}$ \\
\hline
\end{tabular}

\section{CInternational Monetary Fund. Not for Redistribution}




\section{Current Account Liberalization}

Table 5 reports regression results for our tariff reform index. For the growth regression (column 1), the coefficient on the reform indicator is positive and significant, implying that opening up to international trade increases growth. An increase in the reform index from the median (Ghana or Senegal in 20015) to the $75^{\text {th }}$ percentile (Turkey or Canada in 2005) results in a long run increase in per capita GDP of 15 percent. Tariff reforms increase growth in the restricted sample of LICs and MICs as well. Column 3 of Table 5 reports the results for the inequality regression for tariff reforms. Reductions in tariff rates do not appear to have a significant impact on inequality. ${ }^{19}$ Figure 5 shows the results from the reforms breaks/episodes analysis. There seems to be some (noisy) evidence of an increase in growth following tariff reforms, while inequality seems to decline after large reform breaks (although the increase before the break makes interpretation harder).

Table 6 reports regression results for the current account liberalization index, which measures non-tariff barriers to current account transactions as captured in the IMFs AREAERs database.. For the growth regression (column 1), the coefficient on the current account indicator is positive and significant, implying that liberalizing current account transactions increases growth. An increase in the reform index from the median (Trinidad and Tobago or Honduras in 2005 ) to the $75^{\text {th }}$ percentile (US or any other fully liberalized economy on this dimension) results in a contemporaneous growth effect of 0.25 percent with the long run increase in per capita GDP being 12 percent.

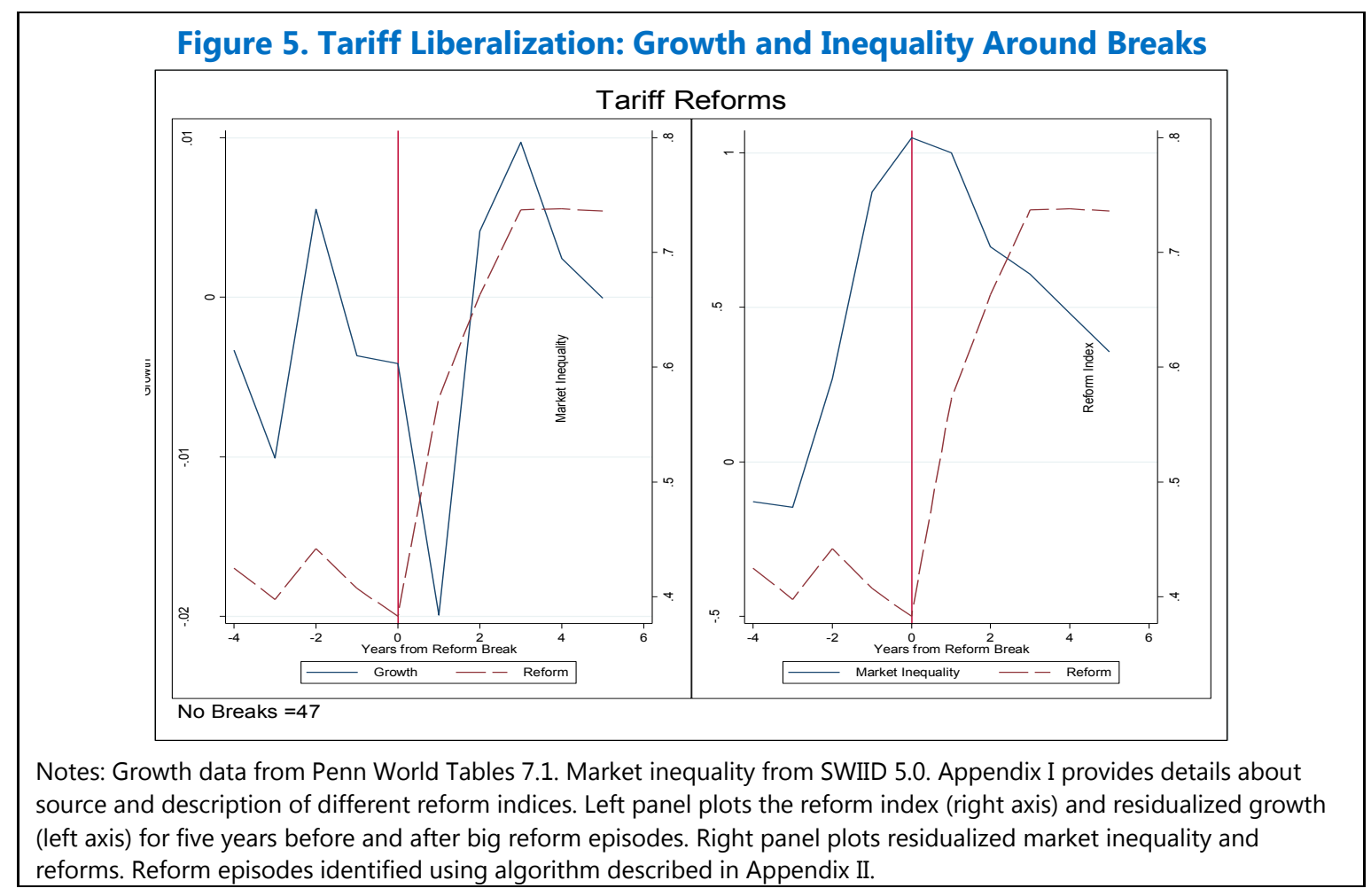

${ }^{19}$ Of course, reduction in tariffs could result in substantial dislocation with workers in one sector or region losing at the expense of gains in other sectors or region with no effect on inequality. 


\begin{tabular}{|c|c|c|c|c|c|c|}
\hline VARIABLES & $\begin{array}{c}1) \\
\text { Growth } \\
\text { All Ctrys } \\
\end{array}$ & $\begin{array}{c}(2) \\
\text { Growth } \\
\text { All Ctrys }\end{array}$ & $\begin{array}{c}\text { (3) } \\
\text { Inequality } \\
\text { All Ctrys }\end{array}$ & $\begin{array}{c}\text { (4) } \\
\text { Growth } \\
\text { LIC\&MIC }\end{array}$ & $\begin{array}{c}\text { (5) } \\
\text { Growth } \\
\text { LIC\&MIC }\end{array}$ & $\begin{array}{c}6) \\
\text { Inequality } \\
\text { LIC\&MIC }\end{array}$ \\
\hline Current Acccount Restrictions & $\begin{array}{l}0.0240 * \\
(0.0131)\end{array}$ & $\begin{array}{c}0.0241 * * \\
(0.0116)\end{array}$ & $\begin{array}{c}0.0096 * * \\
(0.0038)\end{array}$ & $\begin{array}{c}-0.0020 \\
(0.0140)\end{array}$ & $\begin{array}{c}0.0095 \\
(0.0150)\end{array}$ & $\begin{array}{c}0.0095 * * * \\
(0.0034)\end{array}$ \\
\hline Net inequality & $\begin{array}{c}-0.2075^{* * *} \\
(0.0544)\end{array}$ & $\begin{array}{c}-0.1144 * * * \\
(0.0383)\end{array}$ & & $\begin{array}{c}-0.1181 * * \\
(0.0538)\end{array}$ & $\begin{array}{c}-0.0678 \\
(0.0508)\end{array}$ & \\
\hline Log(Investment) & & $\begin{array}{c}0.0337^{* * *} \\
(0.0089)\end{array}$ & & & $\begin{array}{c}0.0285^{* * *} * \\
(0.0094)\end{array}$ & \\
\hline Log(Education) & & $\begin{array}{c}-0.0128^{* *} \\
(0.0063)\end{array}$ & & & $\begin{array}{l}-0.0035 \\
(0.0138)\end{array}$ & \\
\hline Lagged pc GDP & $\begin{array}{c}-0.0082^{* *} \\
(0.0039)\end{array}$ & $\begin{array}{c}-0.0070^{* *} \\
(0.0027)\end{array}$ & & $\begin{array}{l}-0.0070 \\
(0.0059)\end{array}$ & $\begin{array}{l}-0.0081 \\
(0.0067)\end{array}$ & \\
\hline Growth of pc GDP & & & $\begin{array}{c}-0.0299 \\
(0.0251)\end{array}$ & & & $\begin{array}{c}0.0169 \\
(0.0296)\end{array}$ \\
\hline Lagged inequality & & & $\begin{array}{l}-0.0298^{*} \\
(0.0157)\end{array}$ & & & $\begin{array}{c}-0.0382 * * \\
(0.0194)\end{array}$ \\
\hline Effect of Reform (75-50 percentile) & 0.12 & 0.12 & 2.83 & -0.01 & 0.05 & 2.40 \\
\hline Observations & 741 & 714 & 589 & 458 & 432 & 348 \\
\hline No. of Countries & 100 & 93 & 96 & 68 & 62 & 65 \\
\hline No. of Instruments & 71 & 103 & 57 & 61 & 101 & 55 \\
\hline AR2 & 0.110 & 0.196 & 0.980 & 0.134 & 0.195 & 0.580 \\
\hline Hansen & 0.0524 & 0.644 & 0.641 & 0.334 & 0.998 & 0.788 \\
\hline \multicolumn{7}{|c|}{$\begin{array}{l}\text { Notes: Data on per capita GDP growth and investment from Penn World Tables 7.1. Total education from Barro and Lee (2012). Net and market inequality from } \\
\text { SWIID } 5.0 \text {. Details of reform variable in Appendix I. First column reports results of a standard growth regression (equation 1). Column } 2 \text { adds additional controls to } \\
\text { the growth regression. Column } 3 \text { reports results for the dynamic inequality regression (equation 2) with change in market inequality on the LHS. Columns } 4 \text { to } 6 \\
\text { repeat the same regressions but for the restricted sample of LICs and MICs only. Row "Effect of Reforms" reports the effect on pc GDP (in percent) and inequality } \\
\text { (in gini points) in the long run ( } 30 \text { years) of moving the reform index from the median to the } 75 \text { th percentile. All regressions include country and time fixed effects. } \\
\text { Estimation done using system GMM. P-value of Hansen and AR2 test reported. Robust standard errors clustered at country level in brackets. *** p<0.01, ** } \\
\text { p<0.05, * p }<0.1\end{array}$} \\
\hline
\end{tabular}

Perhaps somewhat surprisingly, for the restricted sample of LICs and MICs only, there does not seem to be a clear growth benefit from liberalizing current account restrictions. However, this result masks substantial heterogeneity across countries. In particular, if we add an interaction of the reform variable with an index of a countries level of corruption (higher values of index implying lower levels of corruption), we find that the interaction is positive and significant. This suggests that the growth benefit of current account reforms depends crucially on the broader institutional environment in the country, with high levels of corruption associated with lower (or even negative) growth effects. ${ }^{20}$

For the inequality regression (column 3), the coefficient on the current account liberalization index is also positive and significant, indicating that liberalizing the current account can increase inequality. In the full sample, moving the index from the median to the $75^{\text {th }}$ percentile increases inequality by 2.83 gini points while for LICs and MICs the increase in 2.40 points.

Figure 6 shows the results from the reforms breaks/episodes analysis. There seems to be some (again noisy) evidence of an increase in growth following current account liberalization, but no clear impact on inequality. Overall, we find that opening up to trade is beneficial for growth, but the impact on inequality is ambiguous. Broad-based trade reforms which reduce tariffs do not lead to inequality increases on average. However, reforms which remove non-tariff trade barriers do seem to increase inequality.

\footnotetext{
${ }^{20}$ In addition to the current account index, the interaction of the reform variable with corruption is positive and significant for the capital account and network index (reported below) only.
} 
Figure 6. Current Account Liberalization: Growth and Inequality Around Breaks

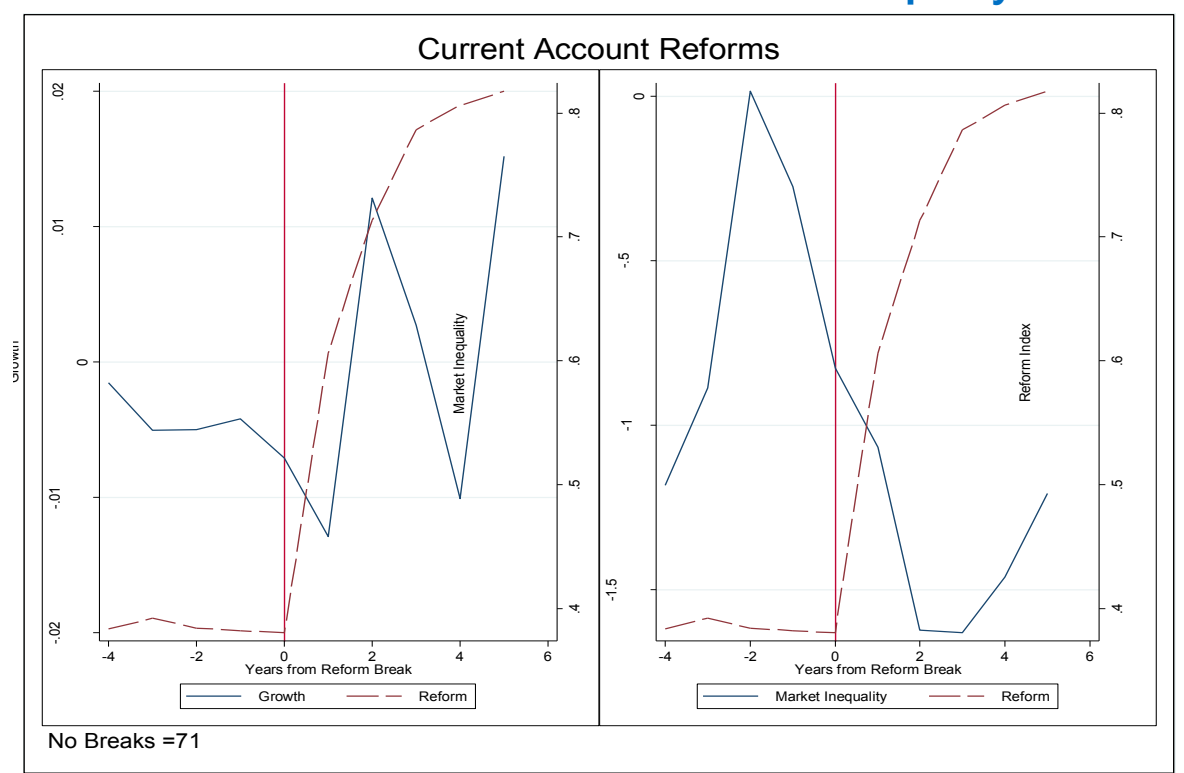

Notes: Growth data from Penn World Tables 7.1. Market inequality from SWIID 5.0. Appendix I provides details about source and description of different reform indices. Left panel plots the reform index (right axis) and residualized growth (left axis) for five years before and after big reform episodes. Right panel plots residualized market inequality and reforms. Reform episodes identified using algorithm described in Appendix II.

\section{E. Networks Reform}

Table 7 reports the regression results for the networks reform index, which measure the extent of competition and quality of regulations in the telecommunications and electricity sectors. Network reforms do not appear to increase growth in any country grouping (a finding that echoes earlier studies by the IMF using similar data, but in contrast to more recent studies for advanced countries using a different, more granular approach). ${ }^{21}$ However, as with current account reforms, the effect of reforms on growth differs markedly across countries, with the interaction between network reforms and corruption being positive and significant, at least for the restricted sample of LICs and MICs. In countries with high levels of corruption, network reforms might lead to the creation of extractive monopolies that do not deliver the expected efficiency gains.

Furthermore, these reforms seem to be associated with higher inequality. Moving the reform indicator from the median (India in 2005) to the $75^{\text {th }}$ percentile (Australia in 2005) increases inequality by 2.34 gini points (column 3 ) when looking at all countries, and by 4.31 gini points (column 6) when only focusing on LICs and MICs.

\footnotetext{
${ }^{21}$ Bouis, Duval and Eugster (2016) and IMF (2016) focus on reduction in barriers to entry in six network industries and find sizable effects on output and productivity in those industries, for a sample of OECD countries. Our measure of network reforms measures a broader concept of liberalization in network industries, including changes in regulation and competition. Ostry et al. (2009) and Prati et al. (2013) using similar data to the ones here for a broad sample of countries also did not find significant growth effects of network industries reforms.
} 
Figure 7 shows the results from the reforms breaks/episodes analysis. The graphs point in the same direction as the results from the regression, with network reform episodes being associated with higher inequality but not higher growth.

\section{F. Collective Bargaining Reforms}

Table 8 reports the regression results for the only aspect of labor market reforms for which we have sufficiently comprehensive data - the collective bargaining index. As with network reforms, the coefficient on the collective bargaining index is not significant in the growth regressions (though it is usually positive). The positive effect is consistent with the idea that more decentralization increases the role of price signals in the labor market and hence efficiency and growth. However, this result is relatively weak and non-robust which, combined with the contrary conclusion in much of the literature (e.g. Blanchard et al., 2013), suggests taking this result with more than the usual grain of salt.

There is some evidence that labor reforms increase inequality in LICs and MICs (column 6): the coefficient on the collective bargaining index is positive indicating that more decentralized bargaining systems (higher values of the index) are associated with higher levels of inequality. While less centralized systems may deliver more employment, they are likely to increase wage inequality, with the latter channel seemingly dominating in the macro data; reduced bargaining power of labor in a more decentralized system may also induce greater inequality. ${ }^{22}$

Figure 8 shows how growth and inequality evolve around reform upbreaks in the collective bargaining index while Figure 9 does the same for downbreaks. The graphs indicate that reforms which result in more (less) decentralized bargaining have no substantial effect on growth but increase (decrease) inequality. As noted above, this result needs to be interpreted with caution because of possible issues with data quality as well as the fact that the index covers only a very specific aspect of labor market reforms.

To summarize, Figures 10 and 11 portray our results in graphical form for all the reform indices. Figure 10 plots the long run change in per-capita GDP (in percent) and the Gini coefficient (in gini points) following structural reforms, thus showing the trade-offs between equity and efficiency that these reforms entail in the medium to long term. Figure 11 plots the impact effect on growth of moving the reform indicator from the median to the $75^{\text {th }}$ percentile i.e., it plots $\gamma_{1} \Delta S R$ where $\Delta S R$ represents the change in the reform index.

\footnotetext{
22 Jaumotte and Osorio Buitron (2015), focusing on advanced economies, show that top income shares increase following erosion of union power. However, they also find some evidence for higher inequality following broad extension of collective agreements to non-union members, likely owing to higher unemployment. Although we use a very different measure for collective bargaining, the fact that we find bigger effects on inequality in LICs and MICs is potentially consistent with their findings for advanced economies.
} 
Table 7. Networks Reforms: Growth-Equity Trade-off

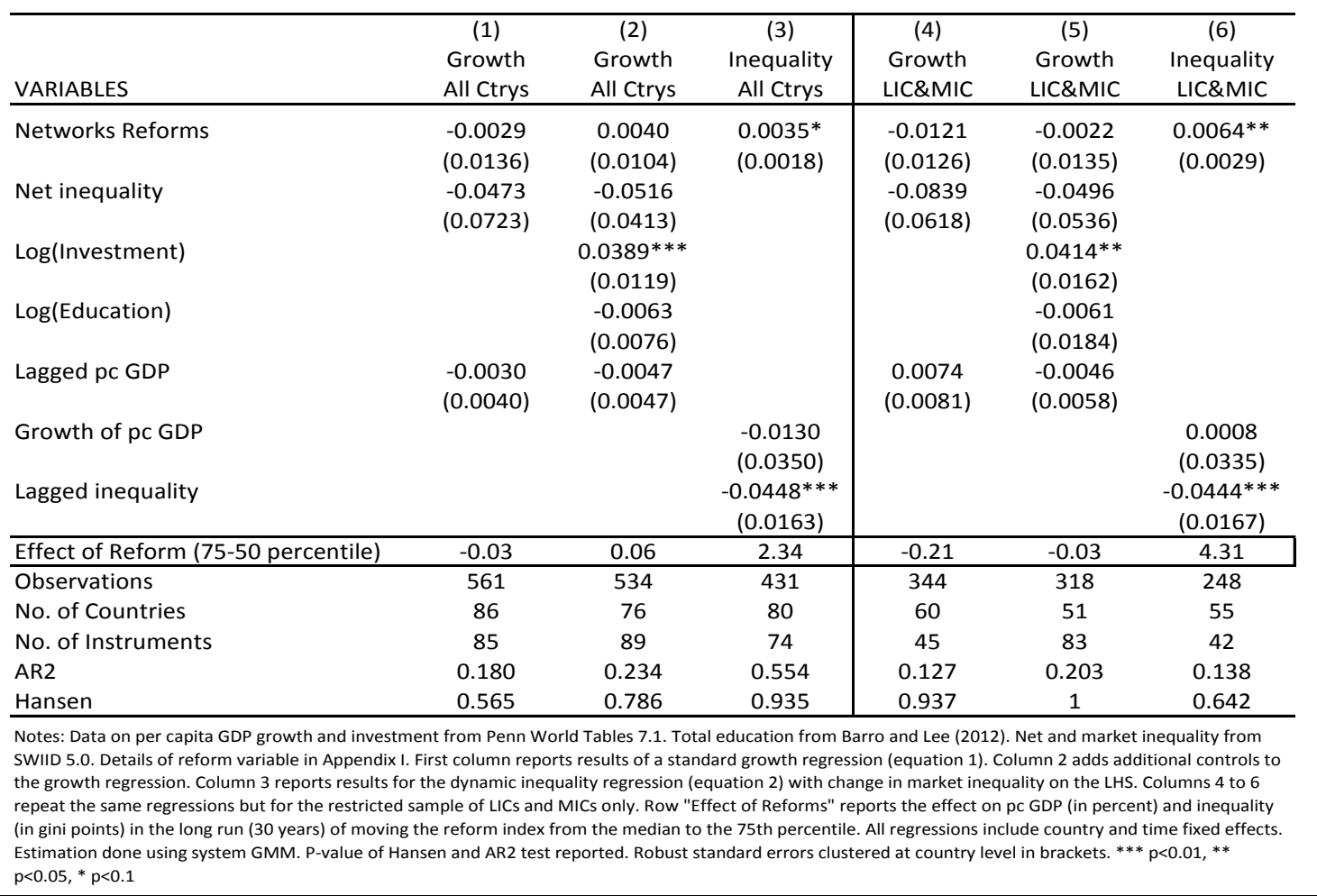

Figure 7. Network Reforms: Growth and Inequality Around Breaks

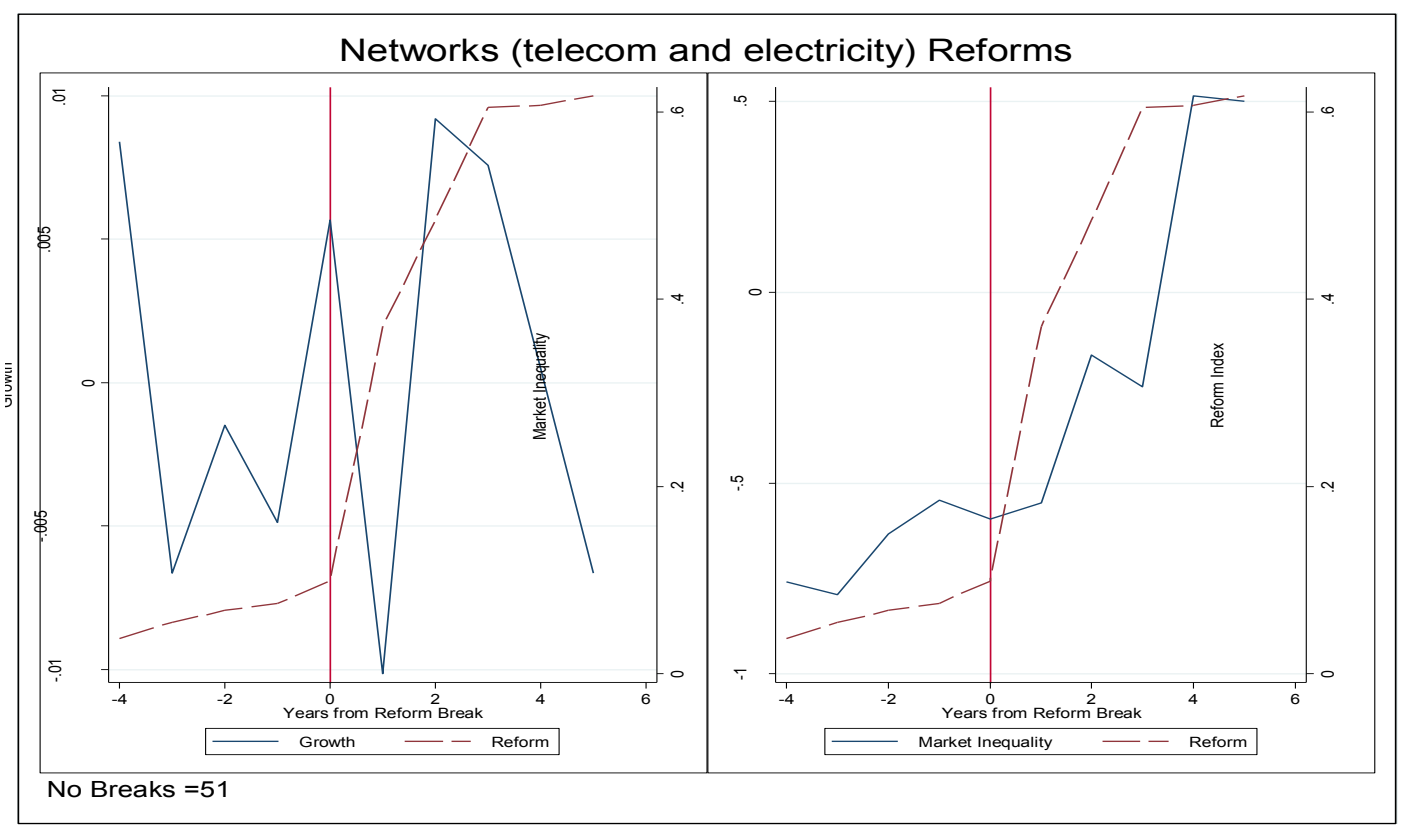

Notes: Growth data from Penn World Tables 7.1. Market inequality from SWIID 5.0. Appendix I provides details about source and description of different reform indices. Left panel plots the reform index (right axis) and residualized growth (left axis) for five years before and after big reform episodes. Right panel plots residualized market inequality and reforms. Reform episodes identified using algorithm described in Appendix II. 
Figure 8. Collective Bargaining: Growth and Inequality Around Up-breaks

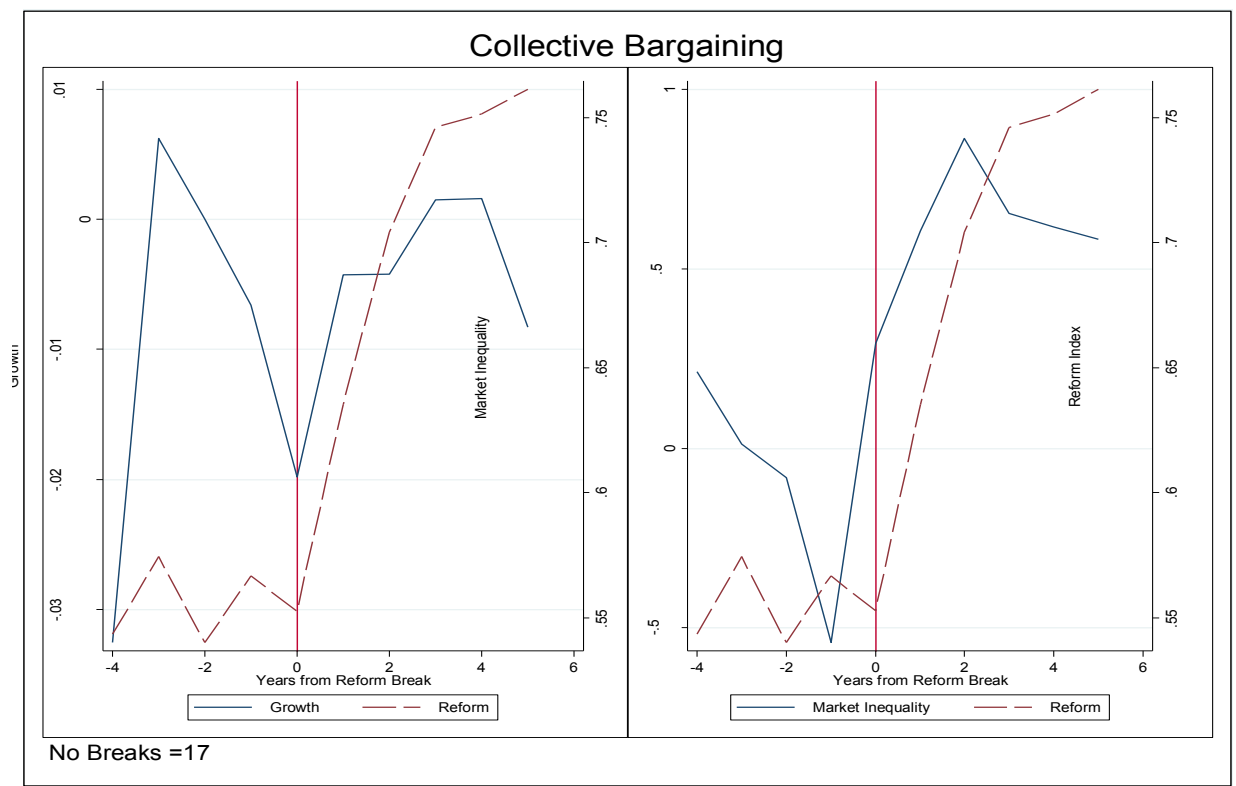

Notes: Growth data from Penn World Tables 7.1. Market inequality from SWIID 5.0. Appendix I provides details about source and description of different reform indices. Left panel plots the reform index (right axis) and residualized growth (left axis) for five years before and after big reform episodes. Right panel plots residualized market inequality and reforms. Reform episodes identified using algorithm described in Appendix II.

Table 8. Collective Bargaining Reforms: Growth-Equity Trade-offs

\begin{tabular}{|c|c|c|c|c|c|c|}
\hline VARIABLES & $\begin{array}{c}(1) \\
\text { Growth } \\
\text { All Ctrys }\end{array}$ & $\begin{array}{c}(2) \\
\text { Growth } \\
\text { All Ctrys }\end{array}$ & $\begin{array}{c}\text { (3) } \\
\text { Inequality } \\
\text { All Ctrys }\end{array}$ & $\begin{array}{c}\text { (4) } \\
\text { Growth } \\
\text { LIC\&MIC }\end{array}$ & $\begin{array}{c}\text { (5) } \\
\text { Growth } \\
\text { LIC\&MIC }\end{array}$ & $\begin{array}{c}\text { (6) } \\
\text { Inequality } \\
\text { LIC\&MIC }\end{array}$ \\
\hline Collective Bargaining & $\begin{array}{c}0.0404 \\
(0.0249)\end{array}$ & $\begin{array}{c}0.0118 \\
(0.0250)\end{array}$ & $\begin{array}{c}0.0027 \\
(0.0060)\end{array}$ & $\begin{array}{c}0.0331 \\
(0.0464)\end{array}$ & $\begin{array}{c}-0.0011 \\
(0.0396)\end{array}$ & $\begin{array}{l}0.0116 * \\
(0.0063)\end{array}$ \\
\hline Net inequality & $\begin{array}{c}-0.0775 \\
(0.0769)\end{array}$ & $\begin{array}{l}-0.0563 \\
(0.0370)\end{array}$ & & $\begin{array}{c}0.0292 \\
(0.1173)\end{array}$ & $\begin{array}{c}0.0428 \\
(0.0873)\end{array}$ & \\
\hline Log(Investment) & & $\begin{array}{c}0.0463^{* * *} \\
(0.0135)\end{array}$ & & & $\begin{array}{l}0.0275^{*} \\
(0.0166)\end{array}$ & \\
\hline Log(Education) & & $\begin{array}{c}0.0102 \\
(0.0172)\end{array}$ & & & $\begin{array}{l}-0.0027 \\
(0.0453)\end{array}$ & \\
\hline Lagged pc GDP & $\begin{array}{l}-0.0040 \\
(0.0044)\end{array}$ & $\begin{array}{l}-0.0076 \\
(0.0052)\end{array}$ & & $\begin{array}{c}-0.0124^{*} \\
(0.0074)\end{array}$ & $\begin{array}{l}-0.0010 \\
(0.0143)\end{array}$ & \\
\hline Growth of pc GDP & & & $\begin{array}{c}-0.0532 * \\
(0.0306)\end{array}$ & & & $\begin{array}{l}-0.0344 \\
(0.0320)\end{array}$ \\
\hline Lagged inequality & & & $\begin{array}{c}-0.0542^{* * *} \\
(0.0149) \\
\end{array}$ & & & $\begin{array}{c}-0.0349 * * \\
(0.0158) \\
\end{array}$ \\
\hline Effect of Reform (75-50 percentile) & 0.24 & 0.06 & 0.54 & 0.15 & -0.01 & 3.19 \\
\hline Observations & 451 & 439 & 431 & 220 & 208 & 212 \\
\hline No. of Countries & 96 & 90 & 95 & 66 & 60 & 65 \\
\hline No. of Instruments & 81 & 81 & 82 & 64 & 80 & 67 \\
\hline AR2 & 0.353 & 0.516 & 0.932 & 0.239 & 0.235 & 0.677 \\
\hline Hansen & 0.717 & 0.733 & 0.926 & 0.996 & 1 & 1 \\
\hline
\end{tabular}


Figure 9. Collective Bargaining: Growth and Inequality Around Down-breaks

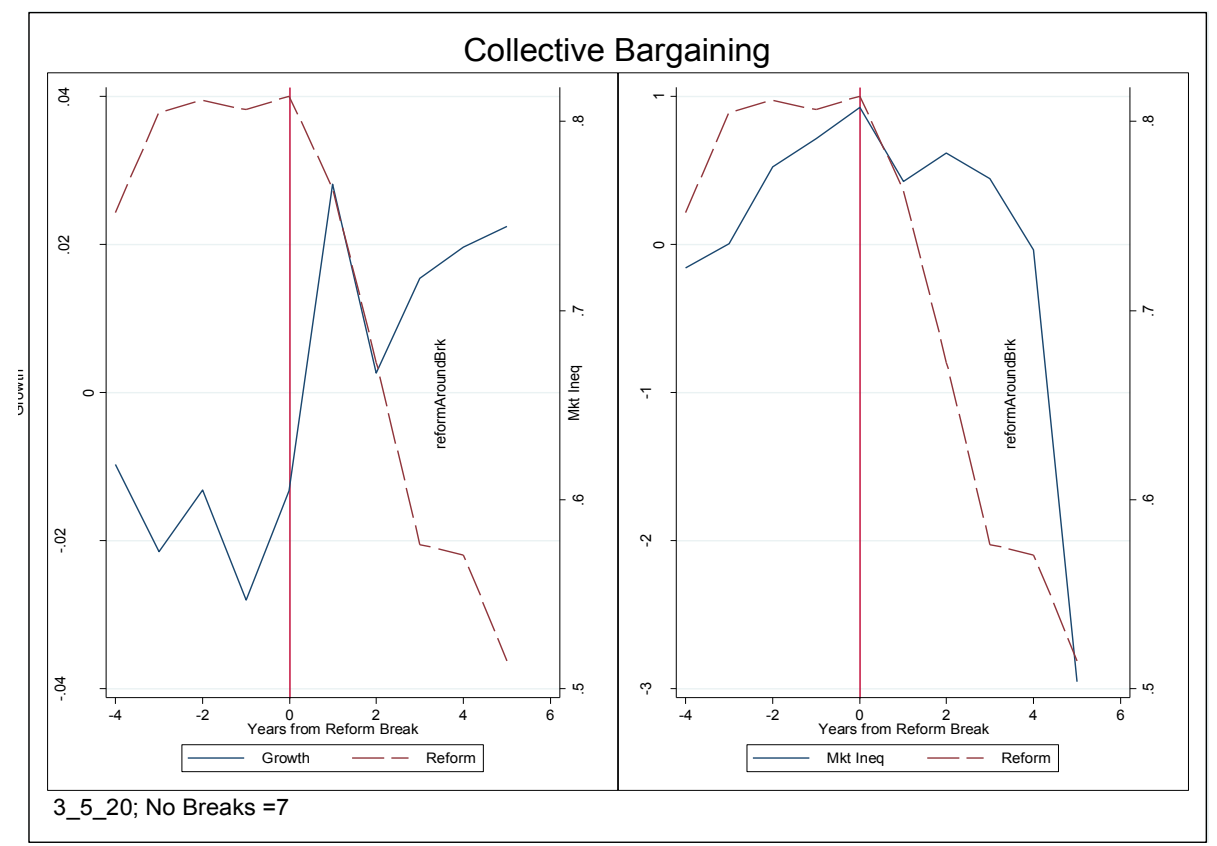

Notes: Growth data from Penn World Tables 7.1. Market inequality from SWIID 5.0. Appendix I provides details about source and description of different reform indices. Left panel plots the reform index (right axis) and residualized growth (left axis) for five years before and after big reform episodes. Right panel plots residualized market inequality and reforms. Reform episodes identified using algorithm described in Appendix II.

\section{G. Reforms, Growth, and Inequality: A Look at Country Cases}

The foregoing sub-sections make the case based on panel regressions and event studies that many reforms raise both growth and inequality. The evidence is based on aggregating over the experience of several countries. Is this evidence also reflected in the narrative histories of - and the political discourse surrounding - growth and inequality of particular countries? To carry out this exercise, we group countries into three categories:

(i) countries where there was a broad-based reform effort in many areas;

(ii) countries where there was a big push on domestic finance or trade;

(iii) countries that have pushed ahead strongly on capital account liberalization or network reforms.

The reform dates are chosen based on combining information from the indices of structural reforms and the event studies. The growth impact from reforms has been studied extensively in previous work. What we look for in the case studies is whether there was also an increase in inequality in the reforms' aftermath, as suggested by our panel regressions and event studies, and whether the narrative gives a sense of the mechanisms discussed in the literature review. Figure 12 plots growth and inequality before and after the reforms for our country cases. 


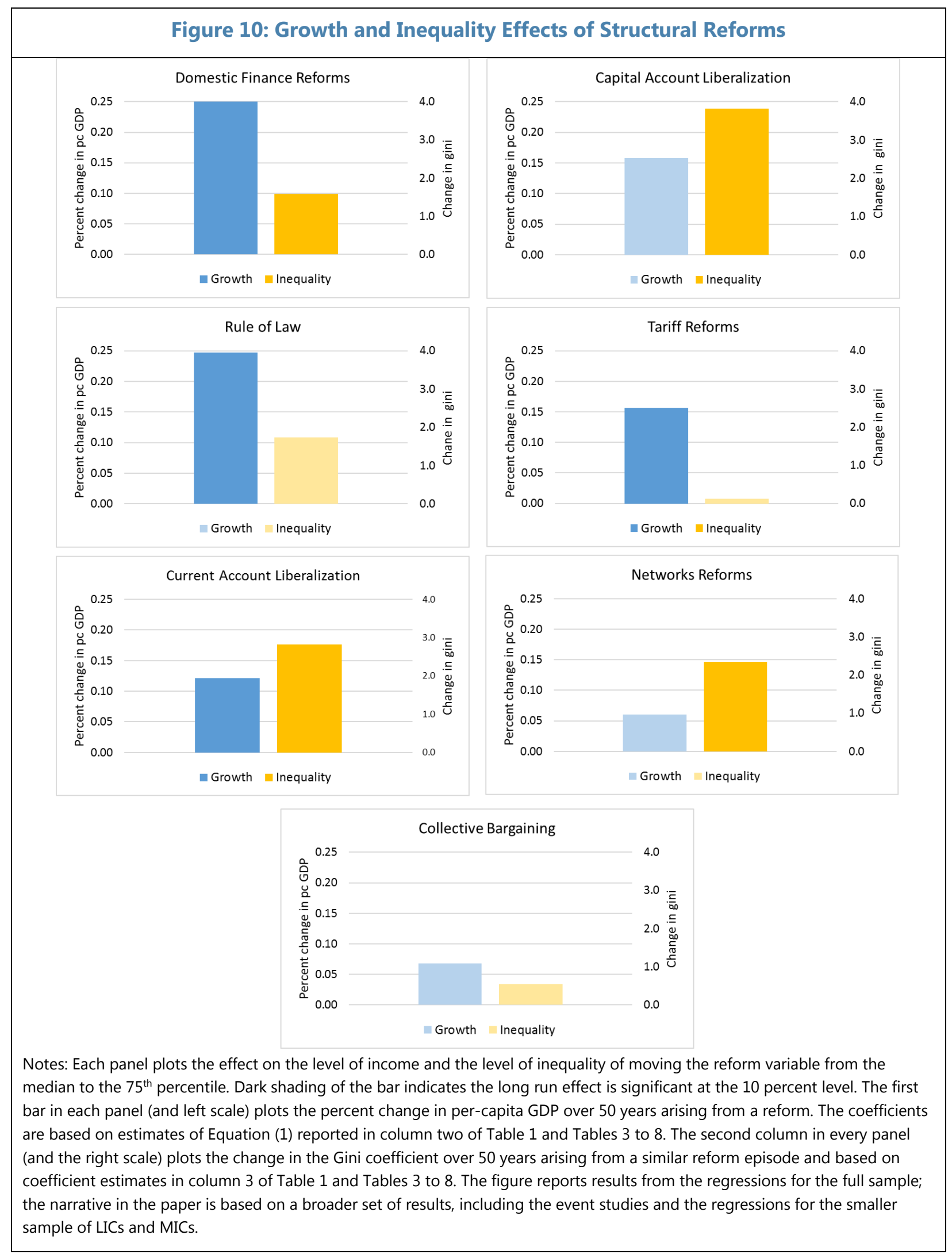

CInternational Monetary Fund. Not for Redistribution 


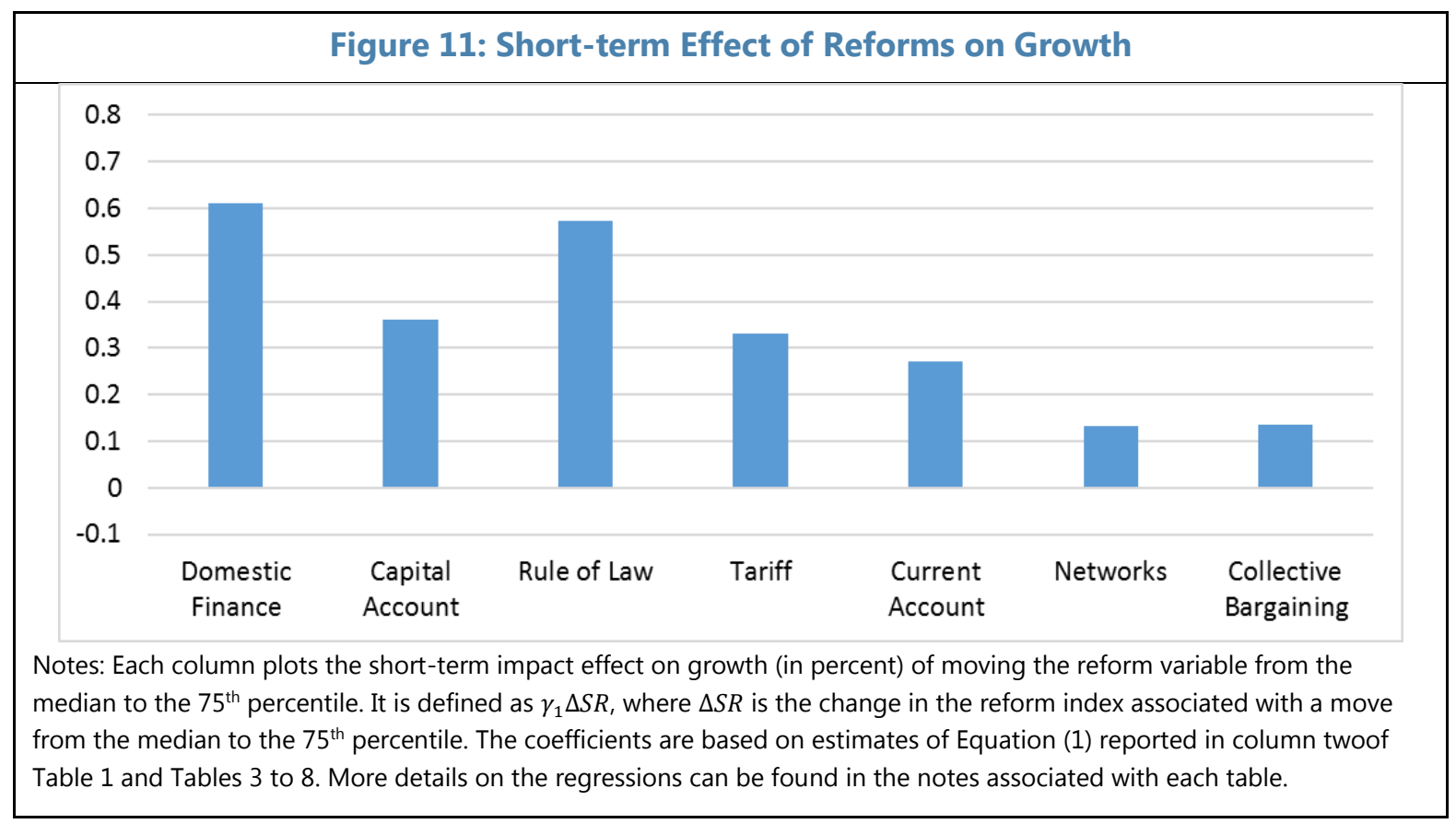

\section{Broad-based reforms}

Australia: In the 1980s and 1990s, Australia implemented extensive domestic financial sector reforms, including removing interest rate controls and some bank lending restrictions, and taking steps to foster increased competition. There was also comprehensive trade liberalization from the late-1980s through the 1990s, including phased reductions in tariffs across sectors. Collective bargaining systems were overhauled to introduce more labor market flexibility. The event study approach above identifies a large domestic finance reform in 1991 and a large network reform in 1996. That Australia experienced a growth payoff from these reforms is widely accepted: the country has enjoyed steady growth over the past two decades. A recent study by Adhikari et al. (2016) uses a rigorous synthetic control method to show that Australia's post-reform output performance has been better than that of a peer group of countries that did not undertake similar reforms.

What is noteworthy is that market inequality has also increased following this period of reform: market Gini rose from 42 in 1991 to 47 in 2005. Concerns about these distributional effects have been part of the political discourse in Australia (Conley, 2004), but were muted by the strong growth performance and by extensive redistributive policies (Greenville et al., 2013).

Tanzania: The country has launched two major waves of reforms. The Economic Recovery Program in 1986 focused on trade and exchange rate liberalization and a second effort in the mid-1990s focused on financial and labor market reforms and on privatization. Reforms paid off in higher growth: Tanzania's per capita GDP growth averaged almost 3 percent a year over the period 1985-2010, substantially higher than its past growth and higher than that of its peers. 
However, contrary to the experience of many other countries that have conducted broad-based reforms, inequality has declined over the period. The country's success in diversifying into labor-intensive manufacturing is often mentioned as a possible reason, but a full explanation of the country's favorable distributional outcomes is still being debated (Atkinson and Lugo, 2014). There is also some concern about more recent distributional developments: Treichel (2005) notes that, despite strong macroeconomic performance between 2001 and 2007, "social and poverty indicators for the country as a whole have not improved substantially over the past decade," with progress on these indicators limited to the capital Dar es Salaam.

In general, countries carrying out broad-based reforms have seen increases in both growth and inequality. Examples include: India (following reform in the mid-1990s); Uganda (1990-95); Costa Rica (1990s); Ghana (late-1980s); Mozambique (mid-1990s); and Rwanda (early 1990s).

\section{Trade-focused and/or domestic finance-focused reforms}

China: Starting in the late-1980s, China embarked on trade liberalization and domestic financial sector reforms. The network reforms and opening up of the capital account have come much later in the reform process; our event study identifies a push on the former in 2001 and on the latter in 2005. Our empirical evidence would suggest a large growth impact initially from the trade and financial sector reforms, perhaps with some moderation as the growth impact of the later reforms is muted according to our evidence; inequality should increase, with the impact likely rising over time as the later reforms have stronger distributional consequences. As is well known, China has enjoyed remarkable growth following the launch of its reforms and this has enabled the rescue of millions from abject poverty. At the same time, inequality has increased dramatically, with large rural-urban income differentials and divergence between coastal and interior provinces (Yang, 1999; Tsui, 1996). Our evidence suggests that as capital account liberalization proceeds, such distributional impacts will grow and steps will be needed, through redistribution and other means, to contain their adverse impacts, including on growth itself. Many other countries in Asia that have followed a similar export-oriented strategy have experienced a similar increase in inequality in recent decades.

Indonesia: Faced with declining oil revenues and balance of payments problems, the Indonesian government moved towards greater market orientation. The financial system was deregulated in two stages, with abolition of most bank lending controls, and the abolition of ceilings on deposit rates at state banks in 1983 and changes in controls to bank borrowing and lending rates and a relaxation of banking entry norms in 1988. "The combination of the June 1983 and October 1988 packages took Indonesia's banking system in just five years from state bank dominance and bureaucratic suffocation to being an effervescent, private sector-driven collection of institutions, remarkably free of government intervention," according to McLeod (1994). Reforms led to increased financial deepening, with private sector credit as a percent of GDP increasing from about 10 percent in 1980 to almost 50 percent in 1990. However, progress on financial inclusion was a lot slower, and Indonesia continues to lag behind Asian peers on the inclusion dimension. Growth picked up in the aftermath of the reforms, so much 
so that Indonesia was hailed as a miracle performer in the decade between the 1988 reforms and the start of the Asian crisis. Over the same period, however, inequality increased, as described by Jayadev (2005): "In the new regime, rapid urban growth (financed by abundant credit) changed employment patterns by moving people from unpaid family labor and the agricultural sector towards urban centers and cities. At the same time, sectors which had provided employment for low skilled workers declined," exacerbating wage differentials.

\section{A thrust toward open capital markets and/or network reforms}

Czech Republic: Among the transition economies, the Czech Republic was a "pioneer ... in achieving a high degree of liberalization of its capital account relatively early in the transition process" (Arvai, 2005). Liberalization of inflows was faster than the removal of outflow restrictions. FDI was the first major item to be liberalized in the early 1990s; most capital transactions were de jure liberalized by September 1995; and OECD accession took place in December 1995. Growth and inequality increased as they did in other transition economies, but some observers note that the Czech Republic underperformed on growth and suffered worse distributional outcomes than other transition economies because it focused excessively on promarket reforms like opening of the capital account but "grossly neglected the need to establish a functioning legal framework and corporate governance of firms and banks" (Svejnar, 2001). In the Czech Republic, the Gini coefficient in the 2000s was 7.5 points higher than in the 1990s, three times more on average than for other Central European transition economies. ${ }^{23}$

Argentina: Our event study identifies a large network reform in Argentina in 1991. This most likely reflects the privatization in 1990 of Empresa Nacional de Telecomunicaciones (ENTel), the Argentine state-owned company which had the monopoly on public telecommunications. The privatization had an immediate macroeconomic impact due to massive job cuts at ENTel; the abrupt adjustment impacted mostly the least-skilled workers, who generally were unable to find jobs. Though rates gradually fell after privatization, they fell much faster in the commercial and long-distance segments most used by the wealthy than in the local tariffs most heavily used by the poor (Galperin, 2005). This case is typical of many in the developing world. Existing empirical literature tends to show that, in developing countries, particularly in Latin America, the end of state monopolies in transportation and telecommunications contributes to income inequality as a result of substantial job loss of low-skilled workers, price increases, and a decline in real output, but with substantial benefits for the powerful and wealthy (Auriol, 2005; McKenzie and Mookherjee, 2003). Though many factors contribute to high inequality in many Latin American countries, these sorts of network reforms are considered to have played an important role as well.

\footnotetext{
${ }^{23}$ We do not include transition economies in our regression analysis as the increase in inequality in these countries was related more to the wholesale transition to the market economy than to any particular structural reform. However, this case is still of interest as it compares the Czech Republic (which implemented capital account liberalization before other reform areas) to other transition countries which also moved away from Communism.
} 


\section{Structural Reforms, Inequality, and Growth: A Simple Calculation}

As seen above, for a number of indicators we find that reforms increase inequality as well as growth. Furthermore, recent studies have found that higher levels of inequality may reduce growth (Ostry et al., 2014 and 2016). This raises the question: what is the total effect of reforms on growth? That is, after taking into account the higher inequality following reforms, how much lower is the effect of reforms on growth (and is it even positive)?

To answer this question, we carry out some simple calculations by combining results from the separate growth and inequality regressions. First, consider the direct effect of reforms on the steady-state level of log of per-capita GDP (holding inequality constant). From equation (1), a change in the reform index from the median to the $75^{\text {th }}$ percentile, denoted by $\Delta S R$, results in a steady-state increase in $\log$ of per-capita GDP of $\frac{\gamma_{1} \Delta S R}{-\beta_{1}}$. Now, the same increase in the reform index leads to a steady-state increase in the gini coefficient of $\frac{\gamma_{3} \Delta S R}{-\beta_{2}}$ (from equation 2 ). The indirect effect of this increase in inequality on per-capita GDP (in steady state) is therefore given by $\frac{\gamma_{2}}{-\beta_{1}} \frac{\gamma_{3} \Delta S R}{-\beta_{2}}$, where $\gamma_{2}$ is the coefficient on inequality in the growth regression. ${ }^{24}$ Finally, the total effect on growth is the sum of direct and indirect effects. ${ }^{25}$ Figure 13 reports results for this calculation. ${ }^{26}$

\footnotetext{
${ }^{24}$ Because the inequality regression includes growth as a regressor, there are potential "higher-round" effects of reform on growth and inequality. The "first round" effect of reform on growth is the "direct effect" discussed in the text. The second round (the "indirect effect" in the text) is due to the fact that reform affects inequality, which in turn affects growth. In a third round, the resulting change in growth could affect inequality which would then further affect growth. And so on. We ignore these third and higher round effects because growth is usually statistically and economically insignificant in the inequality regressions. Indeed, the results are broadly similar if we exclude growth as a regressor in the inequality equation.

${ }^{25}$ An alternative approach to estimate the direct and indirect effect of reforms on per-capita GDP would be to run the growth regressions without inequality as a control variable and compare the effect of reform to that in the growth regression with inequality. However, in a multivariate setting, the regression without inequality is misspecified, yielding inconsistent estimates not only of the coefficient on the reform variable itself but also of the other coefficients, such as that on lagged per-capita GDP (noting that inequality is correlated with lagged percapita GDP). In this multivariate setting, there is no presumption about the effect of omitting inequality on the reform coefficient in the growth regression, even given a view on the effect of reform on inequality and inequality on growth. Thus, the comparison of coefficients on the reform variable in growth regressions with and without inequality may not yield a meaningful estimate of the total effect of reform on income levels.

${ }^{26}$ While the text describes the steady-state direct and indirect effects, in the figure we report long run results over 50 years. This is computed by simulating growth and inequality following the reform. The direct effect assumes that inequality remains constant and traces out the effect of a change in the reform index on growth. For the indirect effect, we simulate the change in gini after reforms by using the inequality regression, and then apply this simulated series to the inequality coefficient estimate in the growth regression. This gives the indirect effect of reforms on growth through the increase in inequality.
} 
Figure 12. Country Cases: Growth, Inequality \& Structural Reform Episodes

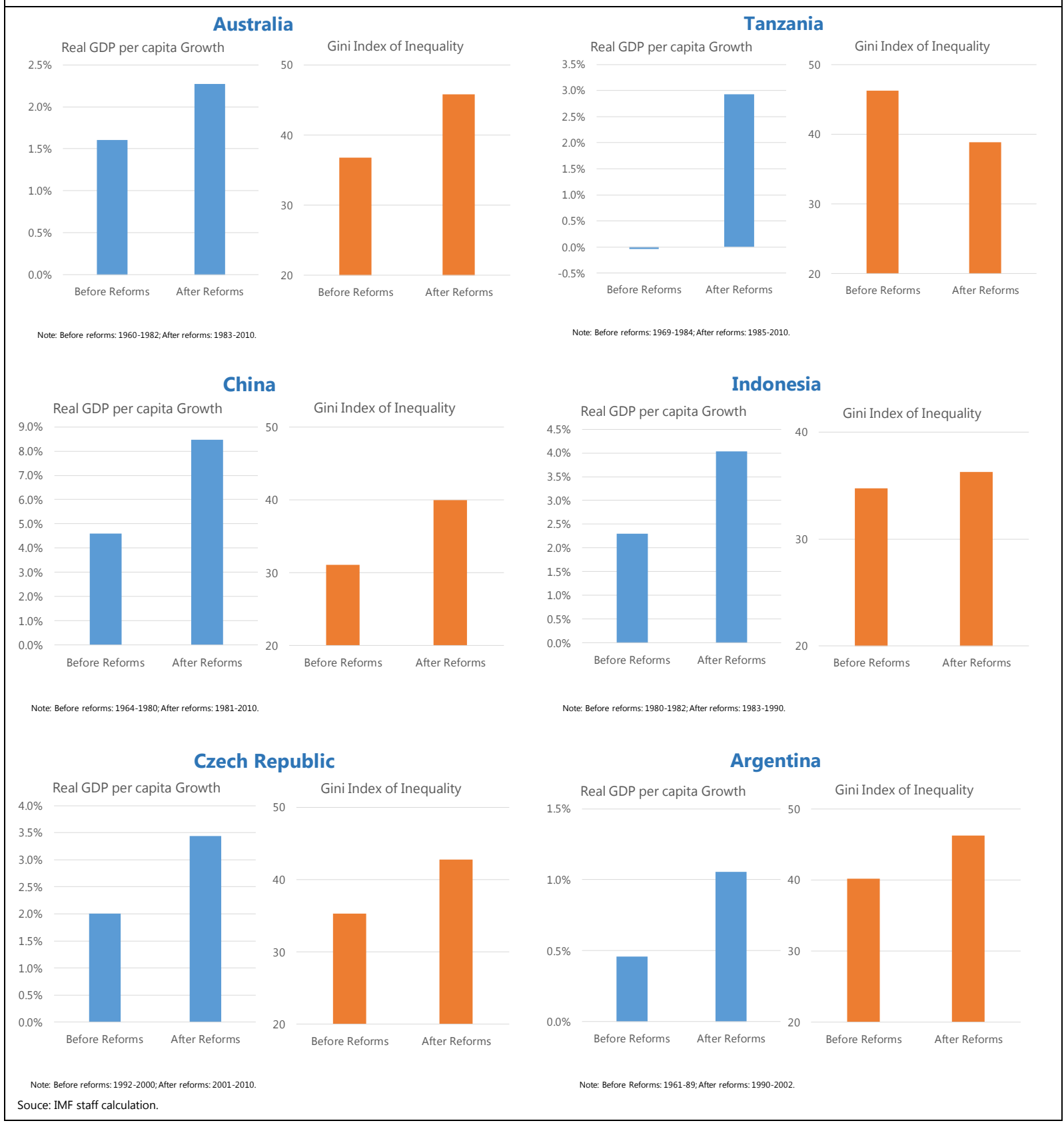

The first panel reports results for the domestic finance variable. The first column in the graph reports the direct effect of an increase in the domestic finance reform index from the median to the $75^{\text {th }}$ percentile. As we can see, such reforms result in a big growth dividend, with long run per capita GDP increasing by about 34 percent. The second column reports the indirect effect on steady-state level of per-capita GDP. The increase in inequality reduces the level of percapita GDP by a modest amount. Finally, the third column reports the total effect, which is significantly positive. Therefore, while the increase in inequality does dampen the effect of reforms on growth, there is still a sizable growth dividend accruing from the reform process. 


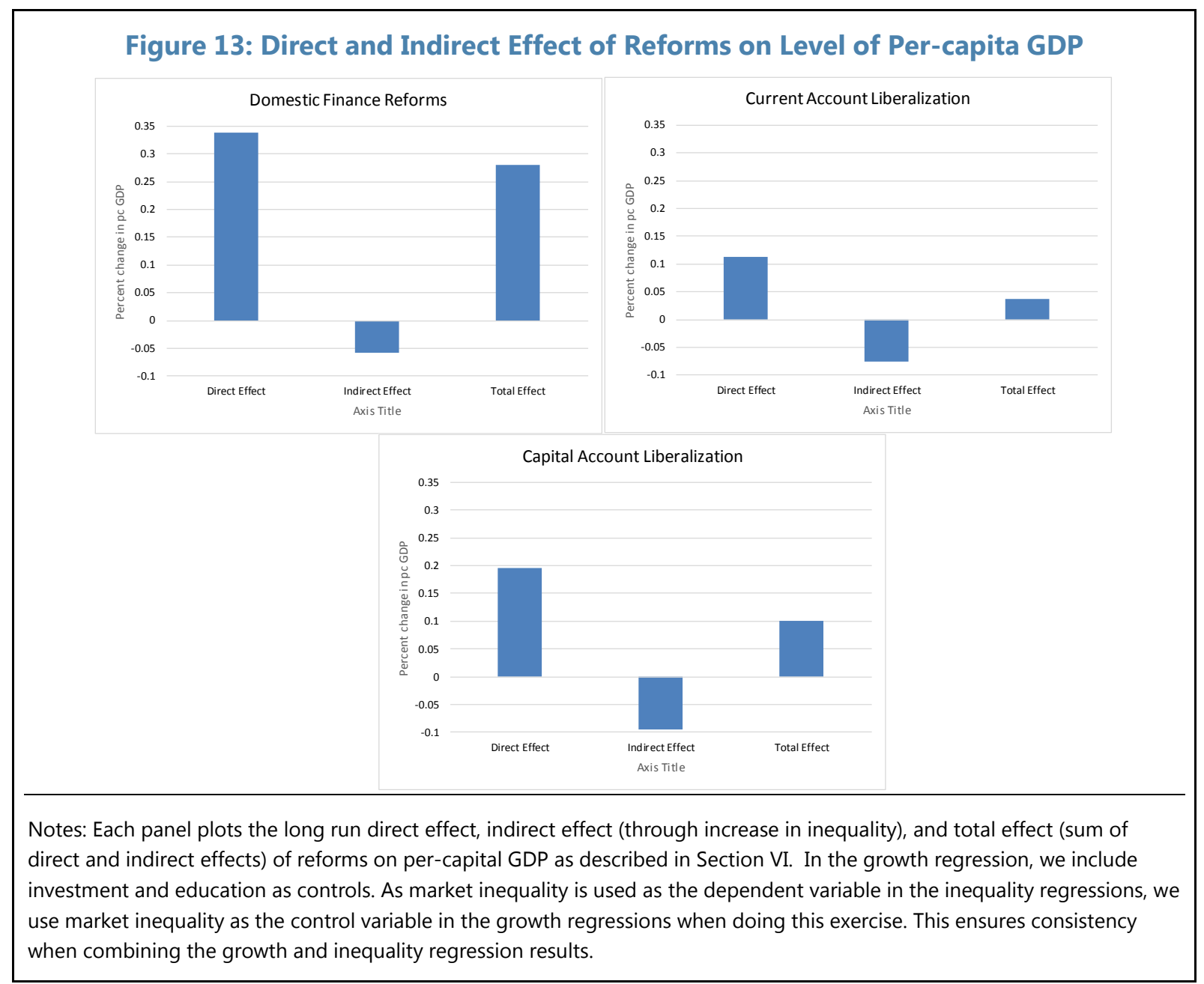

The second panel of Figure 13 reports results for the current account liberalization index. In this case, the indirect negative effect of the reform is about 65 percent of the direct effect, indicating that the increase in inequality can undo a large part of the direct growth effect. Finally, the third panel reports results for the capital account liberalization index. In this case, the total effect is positive, but the negative indirect effect is about 50 percent of the direct effect.

The results on direct and indirect effects documented in this section show that it is important to take into account the effects of reforms on inequality, not just because we care about equity per se, but also to ensure that we maximize the growth dividend from reforms. These calculations indicate what patterns are in the data, but of course they cannot be definitive about the effects of any particular reform. The estimates on which they rely are subject to substantial uncertainty. And they represent average direct and indirect effects of reforms across countries. The effect of any reform on growth and inequality in a particular country will depend on country-specific factors, and reforms that look the same according to these indices may differ in important details. 


\section{CONCLUSION}

In this paper, we have assembled a large cross-country dataset, with a wide range of reform indices, to study the aggregate relation between reforms, inequality and growth. We generally confirm the consensus that structural reforms boost growth. However, reforms also create distributional effects which in turn can reduce growth. We find that the extent of growth-equity tradeoffs varies across reforms. Financial and capital account liberalization seem to increase both growth and inequality, as do some measures of liberalization of current account transactions. Broad institutional reforms aimed at strengthening the impartiality of and adherence to the legal system entail no such tradeoff - such reforms are good for growth and do not worsen inequality. The paper presents more tentative results on collective bargaining and product market reforms - tentative because the quality of the data in these areas is weaker and, also, because the statistical results themselves are less clear-cut-suggesting that decentralization of collective bargaining may increase inequality without raising growth while network liberalization in the electricity and telecoms sectors seems to yield insignificant growth payoffs but may increase inequality.

Our results overall remain supportive of a structural reform agenda. Controlling for the extent of inequality, many such reforms enhance the supply potential of the economy. Moreover, even taking into account the growth-retarding effects of some reforms that operate through an increase in inequality, the total effects of reforms generally remain positive. However, we do not take the view that these positive results rationalize a neglect of distributional considerations. Rather, specific reform packages, in order to gain support and deliver enduring broad-based benefits, need to be designed with distributional consequences in mind.

These results need to be interpreted with caution. The comprehensiveness and broad sweep of our approach comes at the cost that we can only estimate average effects based on highly imperfect (albeit the best and most comprehensive available) measures of reform and inequality. Nonetheless, our results suggest that policymakers who care both about growth and about distribution are right to be concerned about the effects of structural reform on inequality. Our paper serves to put squarely on the policy agenda the need to design reforms intelligently to reduce potential adverse distributional consequences, particularly where inequality is already high and popular support for globalization and for reforms to underpin aggregate supply has been waning. And it also underscores the complementary role that redistributive policies can play in undoing untoward distributional effects engendered by structural reform. 


\section{REFERENCES}

Adhikari, B., R.A. Duval, B. Hu, P. Loungani, 2016. "Can Reform Waves Turn the Tide? Some Case Studies Using the Synthetic Control Method". IMF Working Paper No. $16 / 171$.

Antras P, A. de Gortari, and O. Itskhori, 2016, “Globalization, Inequality and Welfare," NBER Working Paper No. 22676 (Cambridge, Mass: National Bureau of Economic Research).

Arvai, Z., 2005. "Capital Account Liberalization, Capital flow Patterns, and Policy Responses in the EU's New Member States," IMF Working Paper No. 05/213.

Atkinson, A., and M.A. Lugo, 2014, Measuring Growth and Poverty in Tanzania.

Auriol, E., 2005, "Telecommunication Reforms in Developing Countries," Communications \& Strategies, Special Issue, Nov. 2005, pp. 31-53.

Bénabou R., 1996, “Inequality and Growth," NBER Macroeconomics Annual, Volume 11, pp. 11-92.

Banerjee A.V., and E. Duflo, 2003. "Inequality and Growth: What Can the Data Say?" Journal of Economic Growth, 8, pp. 267-299.

Barro, R.J., and J.W. Lee, 2012, "A New Data Set of Educational Attainment in the World, 1950-2010," NBER Working Paper No. 15902 (Cambridge, Mass.: National Bureau of Economic Research).

Bastagli, F., D. Caody, and S. Gupta, 2012. "Income inequality and fiscal policy," IMF Staff Discussion Note 12/08, IMF, Washington.

Beck, T., A. Demirgüç-Kunt, and R. Levine, 2007, "Finance, Inequality and the Poor," J. Econ Growth, 12, pp. 27-49.

Berg, A., and A. Krueger, 2003, “Trade, Growth, Poverty: A Selective Survey,” IMF Working Paper No. 03/30, International Monetary Fund, Washington.

Berg, A. and J.D. Ostry, 2012, “How Inequality Damages Economies," Foreign Affairs, January.

Berg, A., and J.D. Ostry, 2011, "Inequality and Unsustainable Growth: Two Sides of the Same Coin?" IMF Staff Discussion Note No. 11/08, International Monetary Fund, Washington. 
Bergh, A., and T. Nilsson, 2010, "Do Liberalization and Globalization Increase Income Inequality?" European Journal of Political Economy 26, pp. 488-505.

Blanchard, O., F. Jaumotte, and P. Loungani, 2013, "Labor Market Policies and IMF Advice in Advanced Economies During the Great Recession," IMF Staff Discussion Note 13/02.

Bouis, R., R. Duval, and J. Eugster, 2016, "Product Market Deregulation and Growth: New Country-Industry-Level Evidence," IMF Working Paper 16/144.

Claessens, S., and E. Perotti, 2007, "Finance and Inequality: Channels and Evidence,” Journal of Comparative Economics.

Clarke, G.R.G., L.C. Xu, and H.F. Zou, 2006, "Finance and Income Inequality: What Do the Data Tell Us?” Southern Economic Journal, Vol 72, No. 3, pp. 578-596.

Clements, B., R. de Mooij, S. Gupta, and M. Keen, eds., 2015, Inequality and Fiscal Policy, Washington: International Monetary Fund.

Colantone, I., R. Crino and L. Ogliari, 2015, "The Hidden Cost of Globalization: Import Competition and Mental Distress," CEPR Discussion Paper 10874.

Conley, T.J., 2004, Globalisation and Rising Inequality in Australia: Is Increasing Inequality Inevitable in Australia?

Dollar, D., and A. Kraay, 2004, “Trade, Growth, and Poverty,” Economic Journal, Vol. 114, pp. F22-F49.

Dreher A., and N. Gaston, 2008, "Has Globalization Increased Inequality?" Review of International Economics, 16 (3), pp. 516-536.

Duval, R. and D. Furceri (2016), “The Effects of Labor and Product Market Reforms: The Role of Macroeconomic Conditions and Policies", IMF Working Paper (forthcoming).

Fabrizio, S., D. Furceri, R. Garcia-Verdu, B.G. Li, S. Lizarazo, M. Mendes, and A. Peralta, 2016, "Macro-Structural Policies and Income Inequality in Low-Income Developing Countries," Staff Discussion Note (forthcoming), IMF, Washington DC.

Fernández A., M.W. Klein, A. Rebucci, M. Schindler, and M. Uribe, 2015, “Capital Control Measures: A New Dataset,” NBER Working Paper No. 20970.

Frankel, J., and D. Romer, 1999, "Does Trade Cause Growth?” American Economic Review Vol. 89, No. 3, June, pp. 379-99. 
Frazer, G., 2006, "Inequality and development across and within countries," World Development, Elsevier, vol. 34(9), pages 1459-1481, September.

Furceri D., P. Loungani, and J.D. Ostry, 2017, "The Aggregate and Distributional Effects of Financial Globalization," Paper presented at the IMF Polak Annual Research Conference, November, International Monetary Fund, Washington.

Galor, O., and J. Zeira, 1993, "Income Distribution and Macroeconomics," The Review of Economics Studies, Vol. 60, Issue 1, pp. 35-52.

Galperin, H., 2005, "Telecommunications Reforms and the Poor: The Case of Argentina" University of Southern California.

Greenwood, J., and B. Jovanovic, 1990, "Financial Development, Growth, and the Distribution of Income," Chicago Journals, The Journal of Political Economy, Vol. 98, No. 5, Part 1, pp. 1076-1107.

Greenville, J., C. Pobke, and N. Rogers, 2013, "Trends in the Distribution of Income in Australia," Productivity Commission Staff, Working Paper.

Harrison, A., J. McLaren, and M.S. McMillan, 2010, "Recent Findings on Trade and Inequality," National Bureau of Economic Research, Working Paper No. 16425.

IMF, 2008, "Structural Reforms and Economic Performance in Advanced and Developing Countries," International Monetary Fund, Washington, SM/08/166.

IMF, 2012, "Fiscal Policy and Employment in Advanced and Emerging Economies," International Monetary Fund, Washington.

IMF, 2015, "Structural Reforms and Macroeconomic Performance: Initial Considerations for the Fund," International Monetary Fund, Washington.

IMF, 2016, "Time for a Supply-Side Boost? Macroeconomic Effects of Labor and Product Market Reforms in Advanced Countries," in World Economic Outlook, April.

Jahan S., and D. Wang, 2016, "Capital Account Liberalization in Low-income Developing Countries: Evidence from a New Database," IMF Working Paper, Forthcoming, International Monetary Fund, Washington.

Jaumotte F., S. Lall, and C. Papageorgiou, 2013, "Rising Income Inequality: Technology, or Trade and Financial Globalization?” IMF Economic Review, vol. 61(2).

Jaumotte F., C. Osorio Buitron, 2015, "Inequality and Labor Market Institutions," IMF Discussion Note No. 15/14, International Monetary Fund, Washington. 
Jayadeva, A., 2005, "Financial Liberalization and its Distributional Consequences: An Empirical Exploration," University of Amherst dissertation.

Kose, Ayhan M, Eswar S. Prasad, and Ashley D. Taylor (2011), "Thresholds in the process of international financial integration," Journal of International Money and Finance, Elsevier, 30(1), 147-179, February.

Krueger, A.O., 1997, "Trade Policy and Economic Development: How We Learn," The American Economic Review, Vol. 87, No. 1, pp. 1-22.

Larrain, M., 2015, "Capital Account Opening and Wage Inequality," Review of Financial Studies, Society for Financial Studies, vol. 28(6), pages 1555-1587.

Levine, R., 1997, "Financial Development and Economic Growth: Views and Agenda," Journal of Economic Literature, 35 (2): pp. 688-726.

Levine, R., 2005, "Finance and Growth: Theory and Evidence," In Handbook of Economic Growth, Vol. 1, 865-934, edited by Philippe Aghion and Stevenen N. Durlauf; Amsterdam: Elsevier Science.

McKenzie, D., and Mookherjee, D., 2003, "Distributive Impact of Privatization in Latin America: An Overview of Evidence from Four Countries," Economia, 3(2), 161-21.

McLeod, R., 1994, "Control and Competition: Banking Deregulation and Re-regulation in Indonesia," Australian National University, mimeo.

OECD, 2015, “The Effect of Pro-Growth Structural Reforms on Income Inequality," in Economic Policy Reform 2015: Going for Growth, OECD Annual Report, Paris.

Ostry, J.D., P. Loungani and D. Furceri, 2016, “Neoliberalism: Oversold?” Finance and Development 53 (2): pp. 38-43.

Ostry, J.D., 2014, "We Do Not Have to Live with the Scourge of Inequality," The Financial Times, OpEd, March 3, 2014.

Ostry, J.D., A. Berg, and C.G. Tsangarides, 2014, "Redistribution, Inequality, and Growth," IMF Staff Discussion Note No. 14/02, International Monetary Fund, Washington.

Ostry, J.D., A. Spilimbergo, and A. Prati, 2009, "Structural Reforms and Economic Performance in Advanced and Developing Countries," IMF Occasional Paper No. 268, International Monetary Fund, Washington.

Prati, A., M. G. Onorato, and C. Papageorgiou, 2013, "Which Reforms Work and under What Institutional Environment? Evidence from a New Data Set on Structural Reforms", The Review of Economics and Statistics, vol. 95(3), pp. 946-968. 
Quinn, D. P., 1997, “The Correlates of Change in International Financial Regulation," American Political Science Review, 91 (3): pp. 531-551.

Quinn, D.P., and A.M. Toyoda, 2008, "Does Capital Account Liberalization Lead to Growth?" The Review of Financial Studies /v21 n3.

Ravallion, M., 2003, “Inequality Convergence,” Economics Letters 80, pp. 351-356.

Rodrik, Dani, 2011, The Globalization Paradox, Norton and Co.

Roine, J., J. Vlachos, D. Waldenströ, 2009, “The Long-Run Determinants of Inequality: What Can We Learn from Top Income Data?” Journal of Public Economics, pp. 974-988.

Sachs, J.D., and A. Warner, 1995, "Economic Reform and the Process of Global Integration," Brookings Papers on Economic Activity, 1 (25th Anniversary Issue), pp. 1-118.

Solt, F., 2009. "Standardizing the World Income Inequality Database," Social Science Quarterly, Vol. 90, Issue 2, pp. 231-242.

Svejnar, J., 2001, “Transition Economies: Performance and Challenges,” University of Michigan Working Paper.

Treichel, V., 2005, “Tanzania's Growth Process and Success in Reducing Poverty” IMF Working Paper No. 05/35.

Tsui, K.Y., 1996, “Economic Reform and Interprovincial Inequalities in China," Journal of Development Economics, Volume 50, Issue 2, August 1996, Pages 353-368, ISSN 0304-3878.

Williams, Joan C., 2016, "What So Many People Don't Get About the U.S. Working Class," Harvard Business Review, November.

Yang, D.T., 1999, "Urban-Biased Policies and Rising Income Inequality in China." The American Economic Review 89.2, pp. 306-10. 


\section{APPENDIX I: REFORMS DATA}

In this appendix we provide more details about the different reform indices we use.

\section{Domestic Financial Liberalization}

Source: Abiad et al. (2008), following the methodology in Abiad and Mody (2005), based on various IMF reports and working papers, central bank websites, and others.

Details: The index of domestic financial liberalization is an average of six subindices. Five of them relate to banking: (i) interest rate controls, such as floors or ceilings; (ii) credit controls, such as directed credit and subsidized lending; (iii) competition restrictions, such as limits on branches and entry barriers in the banking sector, including licensing requirements or limits on foreign banks; (iv) the degree of state ownership; and (v) the quality of banking supervision and regulation, including power of independence of bank supervisors, adoption of Basel capital standards, and a framework for bank inspections. The sixth subindex relates to securities markets and covers policies to develop domestic bond and equity markets, including (i) the creation of basic frameworks such as the auctioning of T-bills, or the establishment of a security commission; (ii) policies to further establish securities markets such as tax exemptions, introduction of medium and long-term government bonds to establish a benchmark for the yield curve, or the introduction of a primary dealer system; (iii) policies to develop derivative markets or to create an institutional investor's base; and (d) policies to permit access to the domestic stock market by nonresidents. The subindices are aggregated with equal weights. Each subindex is coded from zero (fully repressed) to three (fully liberalized).

Coverage: Starts in 1973 with 72 countries. Ends in 2005 with 91 countries.

\section{Capital Account Reforms}

Source: Based on the methodology in Quinn (1997) and Quinn and Toyoda (2008), drawing on information contained in the Fund's AREAER.

Details: Indicators measuring the intensity of legal restrictions on residents' and nonresidents' ability to move capital into and out of a country. Index originally coded from zero (fully repressed) to 100 (fully liberalized).

Coverage: Starts in 1950 with 60 countries, peaks with 104 countries in 2007. Ends in 2013 with 66 countries.

\section{Law and Order}

Source: Political Risk Service Group, International Country Risk Guide data 
Details: Two measures, each sub-component equals half of the total. The "law" sub-component assesses the strength and impartiality of the legal system, and the "order" sub-component assesses popular observance of the law.

Coverage: Starts in 1984 with 114 countries. Ends in 2013 with 138 countries.

\section{Current Account Reforms}

Source: Based on the methodology in Quinn (1997) and Quinn and Toyoda (2008), drawing on information contained in the Fund's AREAER.

Details: An indicator of non-tariff barriers to current account transactions. The index represents the sum of two sub-components, dealing with restrictions on trade in visibles, as well as in invisibles (financial and other services). It distinguishes between restrictions on residents (receipts for exports) and on non-residents (payments for imports).

Coverage: Starts in 1950 with 60 countries, peaks with 104 countries in 2007. Ends in 2013 with 66 countries.

\section{Network Reforms}

Source: Based on national legislation and other official documents.

Details: Simple average of the electricity and telecom markets sub-indices, which are constructed, in turn, from scores along three dimensions. For electricity, they capture: (i) the degree of unbundling of generation, transmission, and distribution; (ii) whether a regulator other than government has been established; and (iii) whether the wholesale market has been liberalized. For telecom, they capture: (i) the degree of competition in local services; (ii) whether a regulator other than government has been established; and (iii) the degree of liberalization of interconnection changes. Indices are coded with values ranging from zero (not liberalized) to two (completely liberalized).

Coverage: Starts in 1960 with 106 countries. Ends in 2003 with 107 countries.

\section{Collective Bargaining Index}

Source: World Economic Forum, Global Competitiveness Report.

Details: Based on surveys conducted in the countries. This index is based on the answer to the question "Wages in your country are set by a centralized bargaining process $(=1)$ or up to each individual company (=7)".

Coverage: Starts in 1970 with 32 countries. Ends in 2010 with 132 countries. 


\section{APPENDIX II: ALGORITHM FOR FINDING REFORM EPISODES}

This appendix gives details of the algorithm used to identify reform breaks/episodes.

Before describing the algorithm it is useful to define three variables which we compute for every country, reform, year triplet:

1. The highest level of reform index over the next 3 years minus the current level of the reform index. Call this $\mathrm{H}_{-}$fwd3_C. This tells us: what is the maximum reform that has taken place over the next 3 years.

2. The highest level of the reform index over the previous 3 years minus the current level of the reform index - Call this H_prev3_C. If this is large, it tells us that we are in a point where reforms have been reversed recently as the reform index was high in the past but is low now.

3. Compute the difference between the reform index today and the next day. Now sum over all negative values of this difference variable over the next 5 years. Call this

SumNeg_fwd5. If this is large in absolute value, it tells us that a lot of negative reform periods happened in the future, indicating reform reversal.

We use the above three variables to identify breaks using the following steps:

Step 1: Biggest reform period_-find the highest value of the variable $\mathrm{H}_{-}$fwd 3 _C for each country, reform pair (as long as that year saw some positive reform) and consider this to be a break i.e. find the year(s) for which a country saw the largest increase in the reform index over the next three years.

Step 2: Rule out temporary low points_rule out the above if $\mathrm{H}$ _prev3_C is more than half of H_fwd3_C indicating that the reform reversal in the previous 3 years is more than half the maximum reform that has taken place in the next 3 years.

Step 3: If observation gets ruled out, find a new break based on step 1.

Step 4: Rule out reforms which were reversed in the future-rule out if SumNeg_fwd5 is greater than half of $\mathrm{H}_{-}$fwd3_C i.e. rule out if the negative reforms over the next 5 years was more than half the maximum increase in reforms.

Step 5: If observation gets ruled out, find a new break based on step 1.

Step 6: Economic criteria - for each country only consider the first break found above (if multiple were found). Then only consider breaks in which H_fwd3_C was at least $20 \%$ of the range of the reform variable (i.e. $20 \%$ of the difference between the highest and lowest value that the reform variable takes across all countries). 


\section{APPENDIX III: COUNTRY ClASSIFICATION BY INCOME GROUP}

The table below lists the countries which we classify as HICs, MICs, and LICs, as well as the sub-group of advanced economies within HICs (based on WEO definition).

\begin{tabular}{|c|c|c|}
\hline HICs (Advanced) & MICs & LICs \\
\hline $\begin{array}{l}\text { Australia, Austria, } \\
\text { Belgium, Canada, Cyprus, } \\
\text { Denmark, Finland, France, } \\
\text { Germany, Greece, Hong } \\
\text { Kong SAR, Iceland, Ireland, } \\
\text { Israel, Italy, Japan, Korea, } \\
\text { Republic of, Luxembourg, } \\
\text { Malta, Netherlands, New } \\
\text { Zealand, Norway, } \\
\text { Portugal, Singapore, Spain, } \\
\text { Sweden, Switzerland, } \\
\text { Taiwan Province of China, } \\
\text { United Kingdom, United } \\
\text { States }\end{array}$ & $\begin{array}{l}\text { Algeria, Angola, Argentina, Belize, } \\
\text { Bhutan, Bolivia, Botswana, Brazil, } \\
\text { Cameroon, Cape Verde, Chile, China, } \\
\text { Colombia, Congo, Republic of, Costa Rica, } \\
\text { Cuba, Djibouti, Dominica, Dominican } \\
\text { Republic, Ecuador, Egypt, El Salvador, Fiji, } \\
\text { Gabon, Grenada, Guatemala, Guyana, } \\
\text { Honduras, India, Indonesia, Iran, Iraq, } \\
\text { Jamaica, Jordan, Kiribati, Lebanon, } \\
\text { Lesotho, Libya, Malaysia, Maldives, } \\
\text { Mauritius, Mexico, Micronesia, Fed. Sts., } \\
\text { Mongolia, Morocco, Namibia, Nicaragua, } \\
\text { Palau, Panama, Paraguay, Peru, } \\
\text { Philippines, Samoa, Seychelles, South } \\
\text { Africa, Sri Lanka, St. Kitts \& Nevis, St. } \\
\text { Lucia, St.Vincent \& Grenadines, Sudan, } \\
\text { Suriname, Swaziland, Syria, Taiwan } \\
\text { Province of China, Thailand, Tonga, } \\
\text { Tunisia, Turkey, Uruguay, Vanuatu, } \\
\text { Venezuela, }\end{array}$ & $\begin{array}{l}\text { Afghanistan, Bangladesh, } \\
\text { Benin, Burkina Faso, } \\
\text { Burundi, Cambodia, Central } \\
\text { African Republic, Chad, } \\
\text { Comoros, Congo, Dem. Rep., } \\
\text { Cote d'Ivoire, Eritrea, } \\
\text { Ethiopia, Gambia, The, } \\
\text { Ghana, Guinea, Guinea- } \\
\text { Bissau, Haiti, Kenya, Laos, } \\
\text { Liberia, Madagascar, } \\
\text { Malawi, Mali, Mauritania, } \\
\text { Mozambique, Nepal, Niger, } \\
\text { Nigeria, Pakistan, Papua } \\
\text { New Guinea, Rwanda, Sao } \\
\text { Tome and Principe, Senegal, } \\
\text { Sierra Leone, Solomon } \\
\text { Islands, Somalia, Tanzania, } \\
\text { Togo, Uganda, Vietnam, } \\
\text { Yemen, Zambia, Zimbabwe, }\end{array}$ \\
\hline \multicolumn{3}{|l|}{ HICs (others) } \\
\hline $\begin{array}{l}\text { Antigua and Barbuda, } \\
\text { Bahamas, Bahrain, } \\
\text { Barbados, Bermuda, } \\
\text { Brunei, Equatorial Guinea, } \\
\text { Kuwait, Macao, Oman, } \\
\text { Puerto Rico, Qatar, Saudi } \\
\text { Arabia, Trinidad \&Tobago, } \\
\text { United Arab Emirates, }\end{array}$ & & \\
\hline
\end{tabular}

